\title{
External review and validation of the Swedish national inpatient register
}

Jonas F Ludvigsson ${ }^{1,2^{*}}$, Eva Andersson ${ }^{3}$, Anders Ekbom², Maria Feychting ${ }^{4}$, Jeong-Lim Kim³ ${ }^{3}$ Christina Reuterwall ${ }^{5,6}$, Mona Heurgren ${ }^{7}$ and Petra Otterblad Olausson ${ }^{7}$

\begin{abstract}
Background: The Swedish National Inpatient Register (IPR), also called the Hospital Discharge Register, is a principal source of data for numerous research projects. The IPR is part of the National Patient Register. The Swedish IPR was launched in 1964 (psychiatric diagnoses from 1973) but complete coverage did not begin until 1987. Currently, more than $99 \%$ of all somatic (including surgery) and psychiatric hospital discharges are registered in the IPR. A previous validation of the IPR by the National Board of Health and Welfare showed that 85-95\% of all diagnoses in the IPR are valid. The current paper describes the history, structure, coverage and quality of the Swedish IPR.

Methods and results: In January 2010, we searched the medical databases, Medline and HighWire, using the search algorithm "validat* (inpatient or hospital discharge) Sweden". We also contacted 218 members of the Swedish Society of Epidemiology and an additional 201 medical researchers to identify papers that had validated the IPR. In total, 132 papers were reviewed. The positive predictive value (PPV) was found to differ between diagnoses in the IPR, but is generally $85-95 \%$.
\end{abstract}

Conclusions: In conclusion, the validity of the Swedish IPR is high for many but not all diagnoses. The long followup makes the register particularly suitable for large-scale population-based research, but for certain research areas the use of other health registers, such as the Swedish Cancer Register, may be more suitable.

Keywords: Classification of diseases, disease, epidemiology, morbidity, register

\section{Background}

The Swedish National Inpatient Register (IPR; Swedish: slutenvårdsregistret), also called the Hospital Discharge Register, was established in 1964 (Figure 1). The IPR has complete national coverage since 1987. The IPR is part of the National Patient Register (Swedish: patientregistret). Currently, more than $99 \%$ of all somatic and psychiatric hospital discharges are registered in the IPR. Diagnoses in the IPR are coded according to the Swedish international classification of disease (ICD) system, first introduced in 1964 (adapted from the WHO ICD classification system) (Figure 1). A history of the Swedish and Nordic ICD system has been published elsewhere [1]. It is mandatory for all physicians, private and publicly funded, to deliver data to the IPR (except for visits in primary care). A detailed

\footnotetext{
* Correspondence: jonasludvigsson@yahoo.com

'Department of Paediatrics, Örebro University Hospital, Sweden

Full list of author information is available at the end of the article
}

description of the regulations relevant to the IPR has been given in the Appendix (Additional file 1).

\section{History and coverage of the IPR}

The IPR was founded in 1964 when the NBHW (National Board of Health and Welfare; Swedish: Socialstyrelsen) began collecting data on somatic inpatient care in six Swedish counties (roughly the Uppsala region)(Figure 2, red line) [2] (for the population statistics underlying Figures 2 and 3, please see Additional file 2). In fact, the NBHW started to collect data on psychiatric care in 1962 but when the IPR was reconstructed in the 1990s, all psychiatric data originating before 1973 were removed (Figure 3). Beginning in about 1970, data collection for the IPR went from a pilot project to an all-inclusive effort to cover the entire country. In 1983, approximately $85 \%$ of all somatic care and almost all psychiatric care were reported to the
C Biomed Central

(c) 2011 Ludvigsson et al; licensee BioMed Central Ltd. This is an Open Access article distributed under the terms of the Creative Commons Attribution License (http://creativecommons.org/licenses/by/2.0), which permits unrestricted use, distribution, and reproduction in any medium, provided the original work is properly cited. 


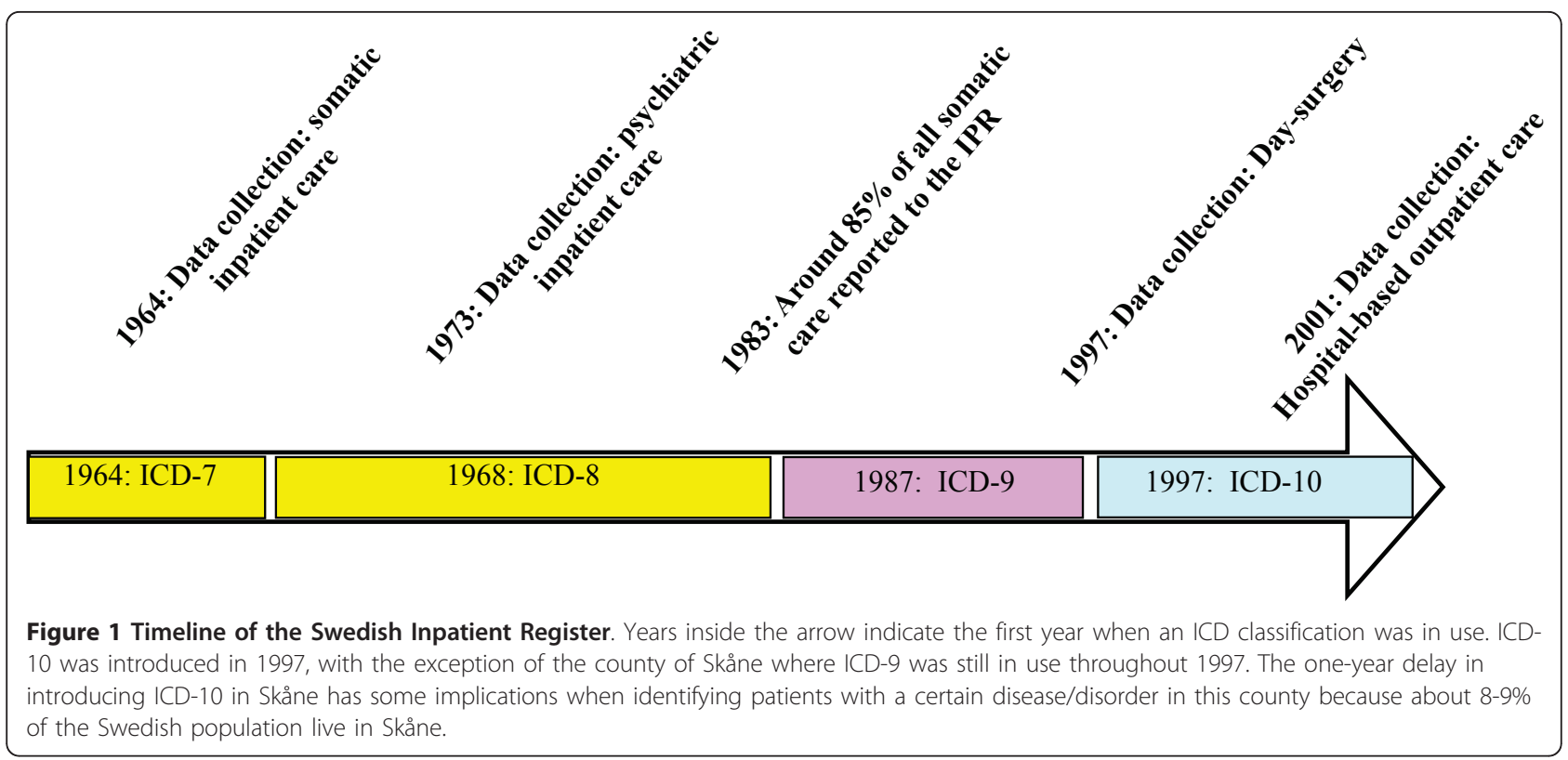

NBHW [2]. In 1984, the NBHW asked permission from the National Data Inspection Board to link individual data to the personal identity number (PIN) (Swedish: personnummer) [3] of each individual. Although granted permission, the NBHW postponed the introduction of a PIN-based register because the Swedish attorney general objected to the use of the PIN in the IPR. Only in 1993 did the Swedish government declare that the IPR should use the PIN as the unique identifier in all hospital discharges. After 1993, all counties have collaborated on reconstructing earlier hospital discharges linked to the PIN for the years 1984-91. This linkage was possible for all but three counties: two counties were unable to reconstruct data for the year 1985 while the third did not enter the IPR until 1987.

Each year, there are about 1.5 million hospital discharges in the IPR (Figure 4), with the majority of these taking place in somatic care. From 1997 and onwards,

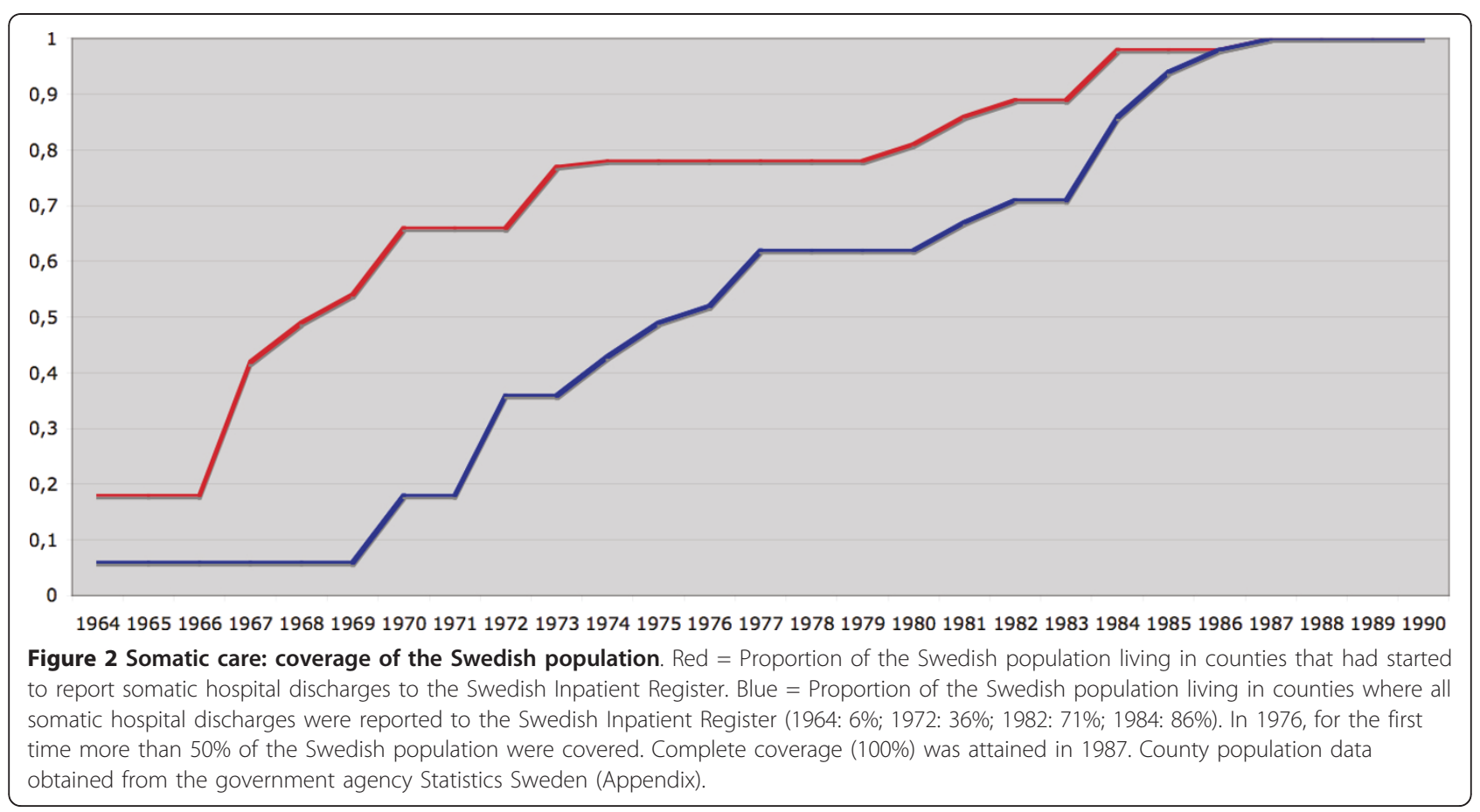




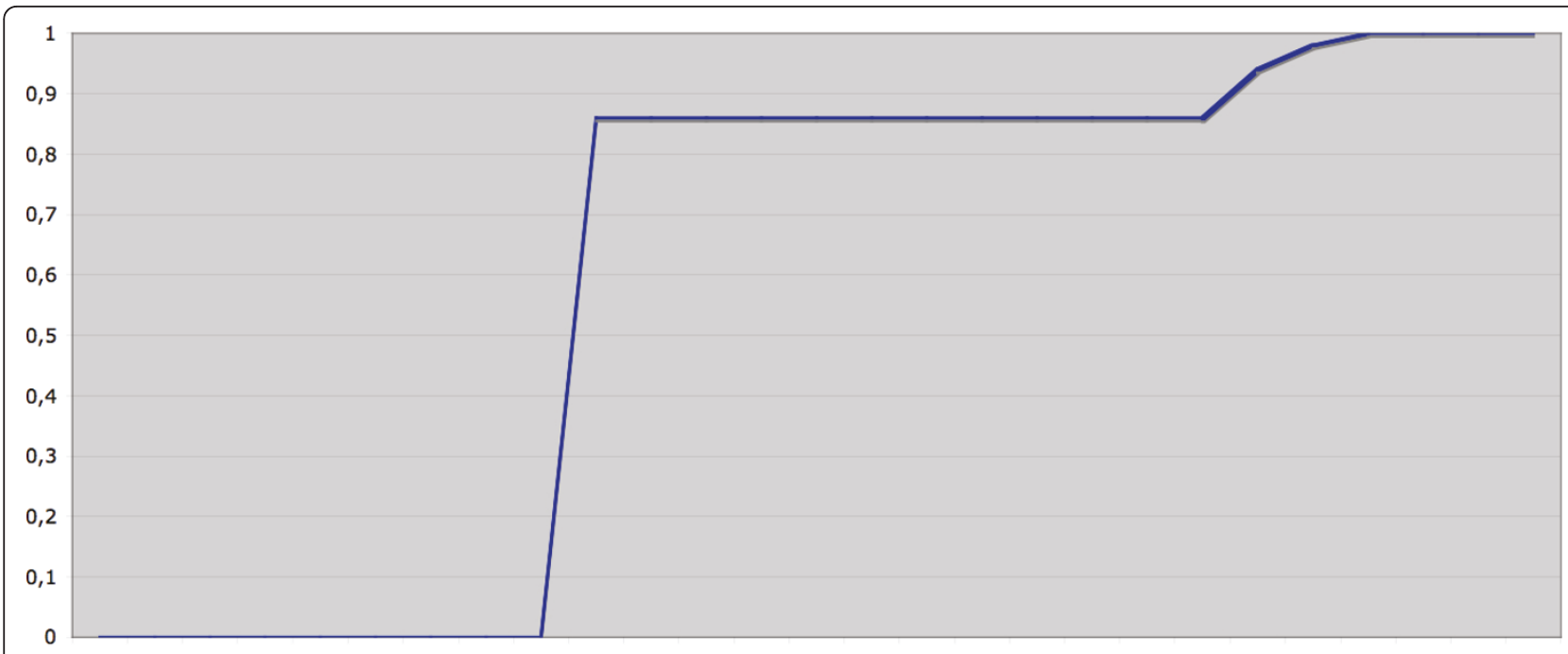

196419651966196719681969197019711972197319741975197619771978197919801981198219831984198519861987198819891990

Figure 3 Psychiatric care: coverage of the Swedish population. Blue = Proportion of the Swedish population living in counties where all psychiatric hospital discharges were reported to the Swedish Inpatient Register (1973: 86\%; 1985: 94\%; 1986: 98\%). All counties in Sweden started to record psychiatric care in 1973. (Actually, psychiatric diagnoses were recorded before 1973 but then removed until 1973 - see text). County population data obtained from the government agency Statistics Sweden (Appendix).

surgical day care procedures are reported to the NBHW, and since 2001, counties are obliged to report hospitalbased outpatient physician visits. However, primary health care data are still not reported on a national level to the NBHW. Whereas coverage of the IPR is currently almost 100\%; coverage of hospital-based outpatient care is considerably lower (about 80\%) [2]. In the outpatient register, data from private caregivers are missing

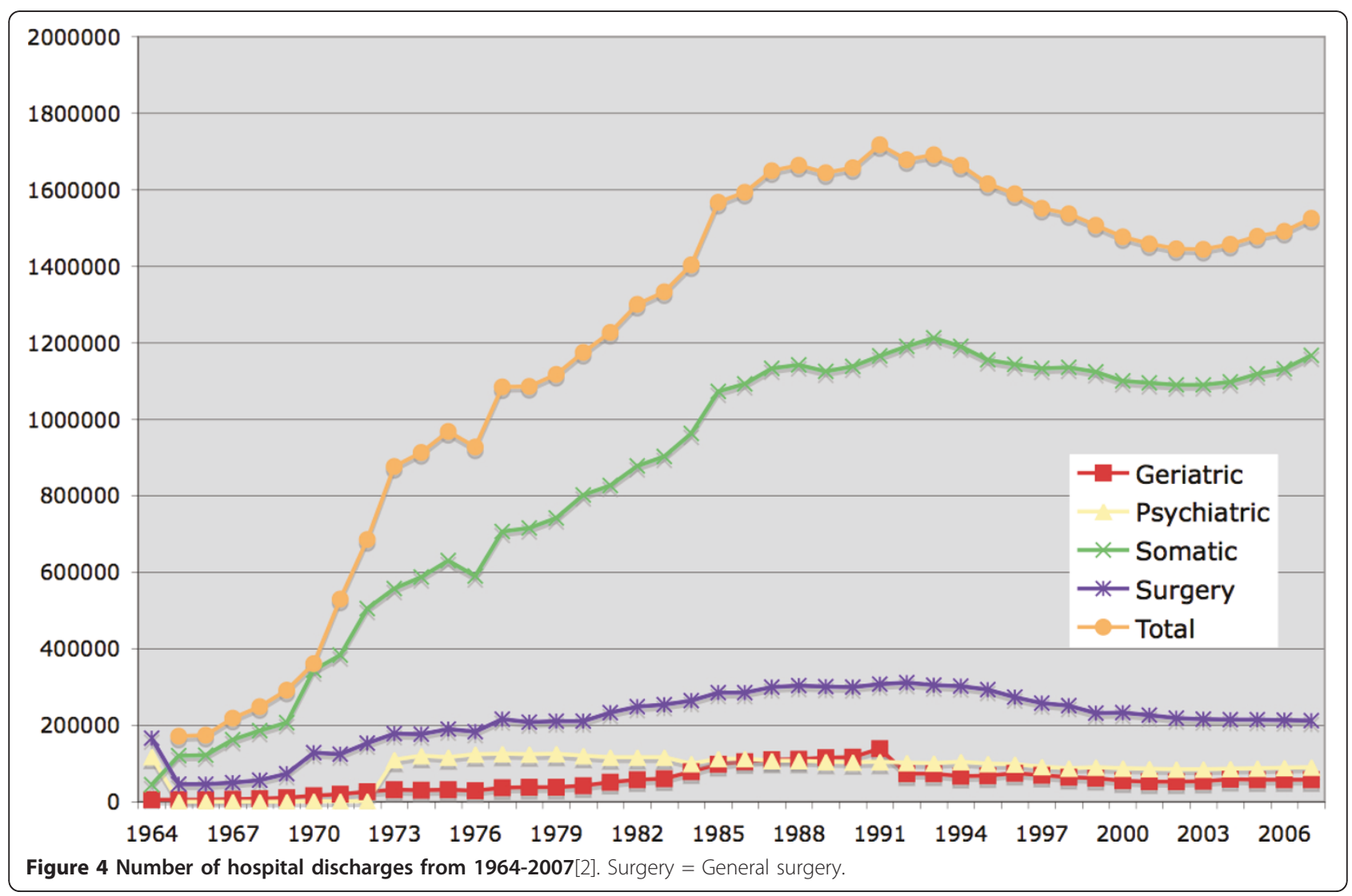


(coverage of data from public caregivers in outpatient care is almost 100\%). The number of hospitals reporting to the IPR increased rapidly in the 1970s. In the 1960s, 20 hospitals and roughly 80 nursing homes reported to the IPR [2]. In the 1980s, the number of units reporting to the IPR had increased to 580. Because of organizational changes, the number of reporting units has since declined.

\section{IPR variables}

IPR variables can be divided into four categories: patientrelated data, data about the caregiver, administrative data and medical data (Table 1). Figure 5 displays a typical dataset from the IPR as delivered to researchers.

The basic unit of the IPR is not the patient but the admission/discharge. Individual patients can be identified by their unique PIN.

\section{Personal identity number (PIN)}

Each hospital discharge is keyed to an individual's PIN [3] (Table 1). Overall (1964-2008), the PIN is found missing in $2.9 \%$ of all hospital discharges.

\section{Primary diagnosis}

Overall, a primary diagnosis is listed in $99 \%$ of all hospital discharges. The highest rate of missing data occurred in 1968 (4.6\%), which may be due to the change from ICD-7 to ICD-8 that occurred in that year. After 2000, missing primary diagnoses have been consistently more common in psychiatric care than in somatic care (5.7$9.4 \%$ in psychiatric care vs. $0.5-0.9 \%$ in somatic care). Since the start of the IPR, primary diagnoses are missing in $0.8 \%$ of somatic care, $2.4 \%$ of geriatric care, $3.1 \%$ of psychiatric care and $0.5 \%$ of general surgery.

The proportion of patients without a primary diagnosis does not differ by hospital type (university hospitals $1.4 \%$, county hospitals $0.7 \%$, small local hospitals $0.8 \%$ ) but is slightly higher in nursing homes (3.1\%).

\section{Injuries and poisoning: external cause}

All hospital admissions for injury or poisoning must be coded by an E code indicating the cause of the injury/ poisoning (Figure 6).

\section{Mode of admission and discharge}

The variables "mode of admission" and "mode of discharge" describe where the patient stays before and after admission, respectively (Table 1). These variables have generally been recorded in more than 95\% of all hospital admissions (with the exception of the year 1979 and in single counties in 1997-2000).

\section{Alternative registers}

Even though the IPR contains important information on a wide spectrum of diagnoses, it is sometimes preferable to use other Swedish health registers, such as the Swedish Cancer Register) [4], the Cause of Death Register [5] and the Swedish Medical Birth Register [6]. There are also a large number of Swedish National Quality
Registers ( $\mathrm{n}=89$ in 2011)(http://www.kvalitetsregister.se, accessed April 19, 2011).

\section{Earlier assessment of the IPR}

The NBHW has previously examined the quality of the IPR on three separate occasions (one published study with data collection in 1986 (899 patients, patient chart validation) [7], one unpublished study with data collection in $1990(\mathrm{n}=875$, patient chart validation) $[2,8]$ and one comparison between the IPR and the National Quality Registers in 2009. The two patient chart studies focused on three types of diagnostic coding error detected in medical records.

1. Diagnostic errors, i.e. the patient received an incorrect diagnosis (the patient receives an ICD code that is not related to his or her actual main complaint). Diagnostic errors were more common in internal medicine records (especially in the 1986 study [7]) than in records from gynaecology departments, and slightly more common in older than in younger patients [2].

2. Translation errors, i.e. the ICD code in the IPR is different from the code actually listed in the patient chart. This type of error was detected in less than $1 \%$ of all medical records.

3. Coding errors, i.e. the faulty ICD code accompanies an otherwise correct diagnosis. Such coding errors occurred in $5.9 \%$ of hospital discharges in 1986 and in $8.3 \%$ in 1990.

In the 1990 validation, the risk of an incorrect primary diagnosis correlated with the number of secondary diagnoses [8]. The overall proportion of incorrect diagnoses at the ICD code 3-digit/character level (e.g., ICD-9: 571 "chronic liver disease and liver cirrhosis") was $13 \%$ in 1986 and 12\% in 1990; at the four-digit level (e.g., ICD-9: $571 \mathrm{E}$ "chronic hepatitis"), it was $15 \%$ in 1986 and $14 \%$ in 1990 (B. Smedby, personal communication, Jan 30, 2010).

The comparison between the IPR and the National Quality Registers found that the IPR has high sensitivity for most surgical procedures (Table 2) [9], whereas sensitivity varied between $76.4 \%$ and $96.0 \%$ for three diseases not requiring surgery (multiple sclerosis, incident stroke and prostate cancer)(Table 2).

\section{Use of the IPR}

Systematic collection of medical data is essential for modern health care because such data are used to plan, evaluate and fund health care. Through the IPR, administrators, health care personnel and researchers are able to (a) evaluate the incidence and prevalence of diseases [10], (b) examine the effects and consequences of interventions (e.g., surgery [11]), including quality of care 
Table 1 Variables in the Swedish IPR

\begin{tabular}{|c|c|}
\hline Variable & Description \\
\hline \multicolumn{2}{|l|}{ Patient-related data } \\
\hline Personal Identity Number (PIN) & $\begin{array}{l}\text { Combination of date of birth, three-digit birth number and a check digit [3]. Personal identity } \\
\text { number shall be reported for all admissions/discharges, except for induced abortions where it is } \\
\text { not registered for legal reasons }\end{array}$ \\
\hline Sex & $1=$ male; 2 = female \\
\hline Age & $\begin{array}{l}\text { Age in years at discharge. In individuals with missing birth dates, the difference between year of } \\
\text { discharge and birth year is used to calculate age. }\end{array}$ \\
\hline County & $\begin{array}{l}\text { The county where the patient has his/her permanent residence (this is not necessarily the county } \\
\text { where the patient is admitted). }\end{array}$ \\
\hline Municipality and parish & $\begin{array}{l}\text { Usually consists of six digits, where positions 1-2 indicate county, 3-4 municipality and 5-6 parish. } \\
\text { Individuals living outside Sweden are assigned the value " } 99 \text { ". Missing data have been replaced by } \\
\text { data from Statistics Sweden. }\end{array}$ \\
\hline
\end{tabular}

\section{Data about caregiver (hospital/department)}

Hospital

Each hospital in Sweden has a unique 5-digit code assigned by the National Board of Health and Welfare (NBHW)(e.g., Lund University Hospital has code 41001).

Type of department

Each type of department or health centre has a unique code assigned by the NBHW (e.g. ophthalmology departments have code 511)

\section{Administrative data}

Admission date

Year-month-day

Discharge date

Year-month-day

Duration of admission

Elective health care

Number of days at hospital. Patients discharged on the day of admission are assigned the value "1".

$1=$ Yes, 2 = No

Mode of admission

1 = from other hospital/department, 2 = from special living (e.g., home for disabled people, or geriatric care), 3 = other (i.e. from home)

Mode of discharge

1 = to other hospital/department, 2 = to special living (e.g., home for disabled people or geriatric care), 3 = other (i.e. discharged to home), 4 = deceased.

\section{Medical data}

Diagnoses

In 1964-1996, the IPR permitted up to 6 diagnoses per discharge. Between 1997-2009 8 diagnoses could be recorded (one of them being the primary diagnosis).

Primary and

additional diagnoses

The primary diagnosis or "main condition" should be the condition diagnosed at the end of the episode of health care responsible for the patient's need for treatment or investigation.

The additional (secondary or contributory diagnoses/conditions) may or may not contribute to the primary diagnosis. They may be co-morbidities and/or complications. Since 2010 the number of possible additional diagnoses per case is unlimited (however, the NBHW will generally only deliver the first 7 additional diagnoses to researchers who request data from the IPR).

External cause of injury or poisoning (E-code) - Until 1997, only one E-code could be recorded per discharge; from 1998, numerous "E-codes" may or "Chapter XX codes". be recorded. With the introduction of ICD-10 in 1997, E-codes should be referred to as "Chapter XX-codes". (In ICD-10, E00-E99 codes represent metabolic conditions).

Procedures In 1964 the Swedish NBHW introduced a national classification of procedures based on an American classification of surgical procedures. It had four digit-codes (e.g. appendectomy 4510). Since 1997, a Swedish version of the NOMESCO Classification of Surgical Procedures is in use. This classification is based on five-character alpha-numeric codes (e.g. JEA01 for appendectomy). Current procedures are listed in the Swedish Classification of surgical and medical procedures (Swedish: "KVÅ" - klassifikation av vårdåtgärder)(issued by the NBHW).

Between 1964 and 1996, up to 6 operations/surgical procedures could be listed per discharge. From 1997, up to 12 operations/surgical procedures could be listed per discharge. In the future it will be possible to record more than 12 diagnoses per discharge. Since 2007, all performed procedures are mandatory to record, including medical procedures. The surgeon may also (voluntarily) report date of operation and type of anaesthesia and drugs used according to the ATC list.

Psychiatric care 0 = voluntary care, 1-4: compulsory psychiatric inpatient care (under different conditions or according to certain laws). If a patient has been treated according to categories 1, 2, 3 or 4, the condition prevailing most of the time shall be reported. Compulsory care can be further divided into "forensic" and "civil", depending on the reasons for compulsory care.

IPR = Inpatient Register. NBHW = National Board of Health and Welfare.

Since January 2009, the NBHW collects additional data on compulsory psychiatric care (psychiatric care under certain laws) in addition to the IPR. The data are collected three times per year.

In older versions of the IPR, the variable "Billing forms (between counties)" was also included. 


\begin{tabular}{|c|c|c|c|c|c|c|c|c|c|c|c|c|c|}
\hline lpnr & SJUKHUS & MVO & KON & ALDER & INDATUMA & UTDATUMA & $\mathrm{AR}$ & VTID & HDIA & EKODI & EKOD2 & INSATT & UTSATT \\
\hline 21 & 51013 & 301 & 2 & 64.00 & 20071008 & 20071009 & 2007.00 & 1.00 & K802 & & & 3 & 3 \\
\hline 31 & 51001 & 301 & 2 & 63.00 & 20070814 & 20070821 & 2007.00 & 7.00 & S270 & W0399 & & 3 & 3 \\
\hline 32 & 22011 & 451 & 2 & 48.00 & 20071127 & 20071130 & 2007.00 & 3.00 & C549 & & & 3 & 3 \\
\hline 32 & 22011 & 451 & 2 & 47.00 & 20070722 & 20070724 & 2007.00 & 2.00 & D259 & & & 3 & 3 \\
\hline 32 & 22011 & 451 & 2 & 47.00 & 20070710 & 20070712 & 2007.00 & 2.00 & D259 & & & 3 & 3 \\
\hline 38 & 51001 & 741 & 2 & 73.00 & 20070507 & 20070511 & 2007.00 & 4.00 & Z511 & & & 3 & 3 \\
\hline 74 & 11001 & 451 & 2 & 20.00 & 20070604 & 20070607 & 2007.00 & 3.00 & O800A & & & 3 & 3 \\
\hline 84 & 41001 & 301 & 2 & 33.00 & 20070330 & 20070430 & 2007.00 & 31.00 & K631 & Y883 & & 1 & 3 \\
\hline 84 & 41001 & 046 & 2 & 33.00 & 20070330 & 20070330 & 2007.00 & 0.00 & R104 & & & 3 & 1 \\
\hline 84 & 41001 & 301 & 2 & 33.00 & 20070127 & 20070130 & 2007.00 & 3.00 & E668 & & & 3 & 3 \\
\hline
\end{tabular}

Figure 5 A sample of variables from the Swedish Inpatient Register (as seen with the statistics programme SPSS). Each hospital discharge is listed on a row. This means that an individual may occupy several rows in the IPR (first, second, third hospital discharge, etc.). The variable Ipnr (or lopnr) is constructed when the dataset is delivered to the researcher, and serves as unique serial number. In the original IPR dataset, each discharge is linked to a unique Personal Identity Number (PIN)[3]. Please note that the order of the variables above may differ from that in the original IPR dataset.

and (c) establish cohorts of patients with a certain disease [12] or condition.

The primary purpose of this paper was to review and validate the IPR. A second objective was to describe its potential use in population-based epidemiological research.

\section{Methods}

Sorensen et al suggest that administrative databases could be evaluated in three ways [13]:

(a) Through comparison with other independent reference sources

(b) Through patient chart reviews (medical records)

(c) By comparing the total number of cases in different databases

The majority of the evaluations in this paper were based on (b), i.e. patient chart reviews.

\section{Assessment by the current study}

In January 2010, we began identifying papers that might concern the validity of the IPR (Figure 7) using database searches in PubMed and HighWire. We used the following search algorithm: "validat" (inpatient or hospital discharge) Sweden". We also contacted 218 members of the Swedish Society of Epidemiology and another 201 researchers with experience in register-based research. Altogether, we identified 132 papers, all of which were subsequently examined in detail. Tables 3 and 4 list papers that validated the IPR.

\section{Results}

With few exceptions, validation of ICD codes from the IPR was made by comparing registered diagnoses in the IPR with information in medical records (Tables 3 and 4 ). The positive predictive values (PPVs) of IPR diagnoses were $85-95 \%$ for most diagnoses (3-digit level, see Table 3). In a review of patients dying in hospital 90$98 \%$ of patients with a primary discharge diagnosis of malignancy had the same malignancy as the underlying cause of death [5]. In addition, $90.3 \%$ of those with a primary discharge diagnosis of myocardial infarction (MI) had MI as the underlying cause of death and with a similar proportion of those with other vascular

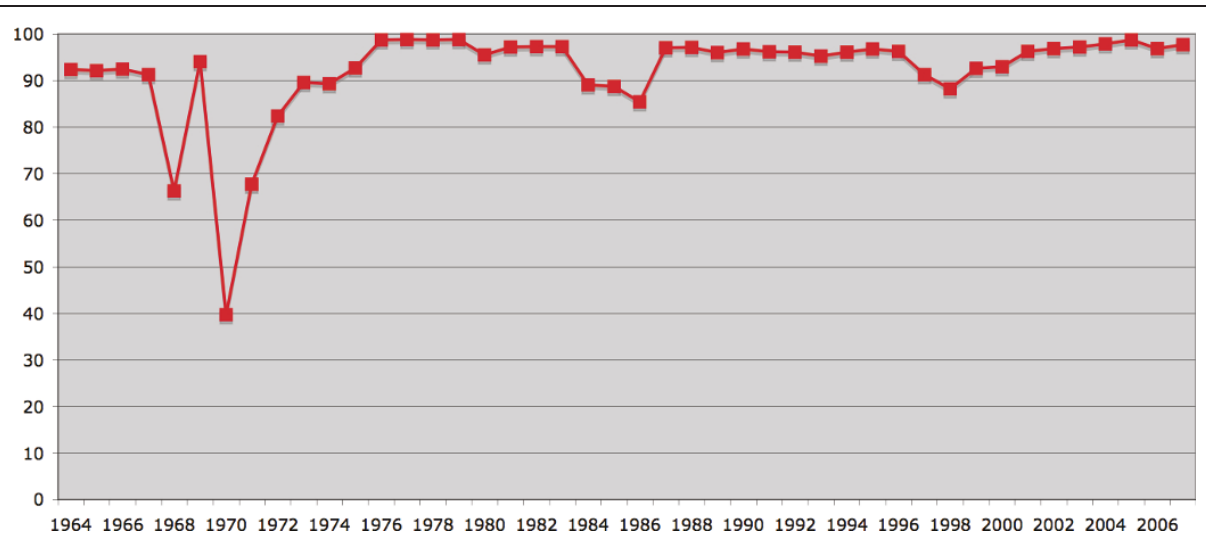

Figure 6 Percentage of hospital discharges for injury and poisoning with reported external cause[2]. 
Table 2 Comparison between Swedish Quality Registers and the National Patient Register [9]

\begin{tabular}{|c|c|c|c|c|}
\hline $\begin{array}{l}\text { Disease/ } \\
\text { Procedure }\end{array}$ & Quality Register & $\begin{array}{l}\text { Total } \\
\text { number of } \\
\text { cases }\end{array}$ & $\begin{array}{l}\text { Matching between the Quality } \\
\text { Register and the Patient Register (\%) }\end{array}$ & $\begin{array}{l}\text { Proportion of all cases identified } \\
\text { through the Patient Register (\%) }\end{array}$ \\
\hline Hernia surgery* & Swedish Hernia Register & 17,707 & 69.9 & 92.5 \\
\hline Cholecystectomy* & $\begin{array}{l}\text { Swedish Register of } \\
\text { Gallstone Surgery and } \\
\text { ERCP }\end{array}$ & 12,472 & 79.9 & 96.4 \\
\hline ERCP* & & 7,458 & 54.5 & 71.2 \\
\hline Multiple Sclerosis* & $\begin{array}{l}\text { Swedish Multiple Sclerosis } \\
\text { Register }\end{array}$ & 13,503 & 52.9 & 76.4 \\
\hline Knee arthroplasty & $\begin{array}{l}\text { The Swedish Knee } \\
\text { Arthroplasty Register }\end{array}$ & 11,122 & 90.1 & 93.6 \\
\hline Hip arthroplasty & $\begin{array}{l}\text { The Swedish Hip } \\
\text { Arthroplasty Register }\end{array}$ & 14,757 & 91.0 & 93.4 \\
\hline Hip fracture & $\begin{array}{l}\text { The Swedish Hip Fracture } \\
\text { Register }\end{array}$ & 15,920 & 64.0 & 95.3 \\
\hline $\begin{array}{l}\text { Surgery on the } \\
\text { abdominal aorta* }\end{array}$ & Swedvasc & 1,784 & 77.4 & 90.6 \\
\hline $\begin{array}{l}\text { Infrainguinal } \\
\text { bypass surgery }\end{array}$ & & 979 & 72.4 & 81.9 \\
\hline $\begin{array}{l}\text { Carotid artery } \\
\text { surgery }\end{array}$ & & 1,584 & 81.6 & 95.2 \\
\hline First stroke & Swedish Stroke Register & 22,202 & 79.4 & 96.0 \\
\hline Heart surgery & $\begin{array}{l}\text { Swedish Heart Surgery } \\
\text { Register\# }\end{array}$ & 13,440 & 95.1 & 97.6 \\
\hline Cataract surgery* & National Cataract Register & 75,050 & 75.2 & 78.6 \\
\hline Prostate cancer* & $\begin{array}{l}\text { National Prostate Cancer } \\
\text { Register }\end{array}$ & 3,985 & 62.0 & 82.8 \\
\hline
\end{tabular}

ERCP = endoscopic retrograde cholangiopancreatography

* Quality register compared with the Patient Register (IPR and hospital-based outpatient data). In the other comparisons the Quality Register was compared only with the IPR.

\# Currently part of the Register Swedeheart.

diseases (89.0\%). Agreement between discharge diagnosis and death certificate was slightly lower for traffic accidents $(87.8 \%)$, meningitis $(74.3 \%)$ and ulcer of the stomach or duodenum (69.9\%) to name a few [5].

Sensitivity of the IPR was high (above 90\%) for MI [14] as well as for surgery for carotid stenosis, surgery on the carotid arteries, or surgery on the arteries in the leg (infrainguinal) and aorta [15] (Table 4) but low for lipid disorders and hypertension [14]. Few studies have examined to what extent an individual without a specific disease is assigned an ICD code for that disease.

Some hospital admissions are due to trauma and not disease. In 2008, Backe et al [16] used ambulance records as gold standard to examine the proportion of injuries and suffocations that were then recorded in the IPR. Agreement between the two data sources varied, with high agreement for "falls" (W00-W19; 93.9\%) but lower for "road traffic accidents" (ICD-10: V01-V99) and "suffocation, drowning/near drowning, etc." (ICD-10: W64-85), where the IPR recorded less than $50 \%$ of all injuries noted in the ambulance reports.

Several studies have examined date of hospital admission. For instance, Nordgren found that for 62\% (257/413) of spinal cord injuries, the hospital admission date agreed with the injury date ( $\leq 2$ days within the injury date [17]).

\section{Discussion}

This review found a high PPV for the majority of evaluated diagnoses but a lower sensitivity. The PPVs reported in this review are similar to those in the Danish IPR (febrile seizures in children: 93\% [18], MIs: 92-94\% [19], venous thromboembolism: $75 \%$ [20]). Furthermore, US hospital data suggest a PPV of about $90 \%$ for some diagnoses (e.g., acromegaly: $76 \%$ of the patients had a definite diagnosis and $14 \%$ a probable diagnosis [21]).

The proportion of valid diagnoses in the IPR is probably higher in patients with severe as opposed to mild disease and higher among patients with causally related complications in contrast to those without complications. Baecklund et al reported that the IPR diagnosis of rheumatoid arthritis was correct in $93.5 \%$ of individuals with later lymphoma but only in $87.1 \%$ in individuals who had not developed later lymphoma [22]. In this case the positive association between lymphoma and rheumatoid arthritis leads to higher specificity for rheumatoid arthritis in patients with lymphoma. 

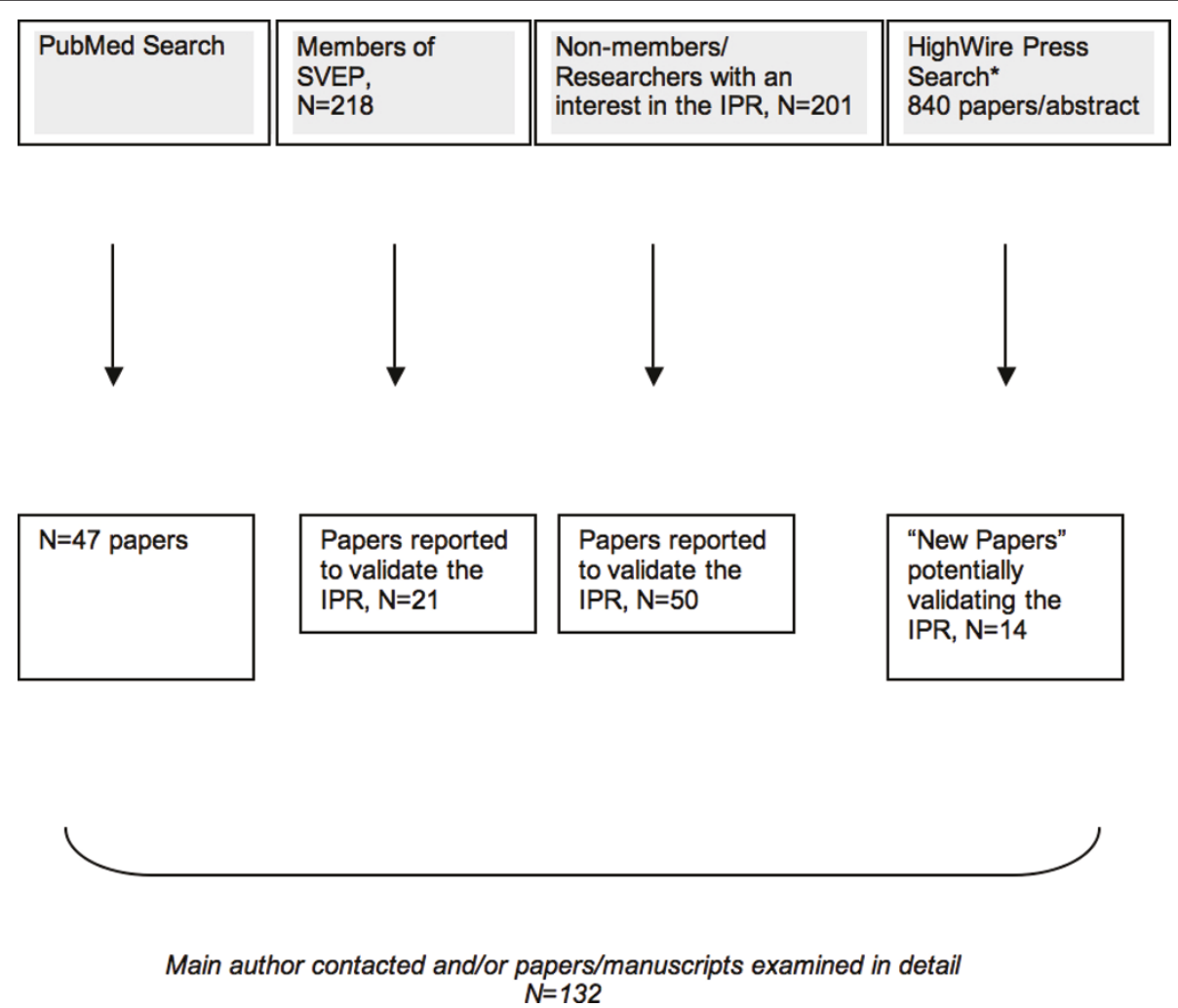

Figure 7 Collection of validation studies. In both the PubMed and HighWire Press search, we used the following search algorithm to identify relevant papers: validat* (inpatient or hospital discharge) Sweden. Databases were searched from the start of the databases until January 2010. *In the HighWire Press literature search, JFL manually screened all titles, authors, keywords and, when available, abstracts for the 840 hits. If a validation of the inpatient register could not be ruled out, the corresponding author was contacted. A number of publications could then be excluded; 14 "new papers" remained that had not previously been identified.

There are several ways to increase the specificity and the PPV of a diagnosis in the IPR. In a paper on sepsis in celiac disease by Ludvigsson et al [23] sensitivity analyses were performed among patients with (1) sepsis diagnosed in a department of infectious diseases (i.e. in a department where sepsis is likely to be correctly diagnosed), (2) sepsis listed as the primary diagnosis and (3) the risk of having at least two hospital admissions with sepsis. All these measures could increase the specificity of a diagnosis. For instance, there is a risk that individuals discharged from a dermatology department with a diagnosis of MI (ICD-10: I20.9) actually had an incorrectly recorded eczema (ICD-10: L20.9). When Parikh et al examined parity and risk of later cardiovascular disease, they restricted their discharges to patients with a primary diagnosis of cardiovascular disease (or death from cardiovascular disease) [24]. In their recent paper on schizophrenia, substance abuse and violent crime Fazel et al resolved to study patients with at least two hospital admissions with schizophrenia [25].

The extent to which a condition has been reported and recorded in the IPR depends on several factors [26], including care-seeking behaviour of an individual, access to health care and the propensity of a physician to admit a patient. Hospital fees, however, are no major obstacle to inpatient care access in that the (public) health system in Sweden is almost free of charge.

Over time, an increasing number of patients are treated as outpatients [27], a trend largely driven by economic restraints but also by data indicating that the prognosis of some diseases (e.g., stroke) has an improved prognosis in ambulatory care [28]. The trend towards outpatient care suggests that the sensitivity of the IPR may have decreased in recent years for some diseases. In fact, our validation showed that the IPR has low sensitivity for hypertension and lipid disorders. The introduction of day care anaesthesia has resulted in that certain procedures, such as small-intestinal biopsy preceding a diagnosis of celiac disease [29], which previously required inpatient care, are nowadays often performed on an outpatient basis.

When Elmberg et al estimated mortality in patients with hereditary haemochromatosis $(\mathrm{HH})$ [30], they found a relative risk of death of 2.15 among $\mathrm{HH}$ patients 
Table 3 Validation of diagnoses in the Swedish Inpatient Register by Positive Predictive Values (PPVs)

\begin{tabular}{|c|c|c|c|c|c|c|}
\hline Diagnosis & $\begin{array}{l}\text { Correct diagnosis in } \\
\text { the IPR }(\%)= \\
\text { positive predictive } \\
\text { value (PPV) }\end{array}$ & Comment & $\begin{array}{l}\text { Main } \\
\text { Author }\end{array}$ & $\begin{array}{l}\text { PubMed } \\
\text { ID }\end{array}$ & Year & $\begin{array}{l}\text { Gold Standard } \\
\text { (reference) }\end{array}$ \\
\hline \multicolumn{7}{|c|}{ Cardiovascular disease } \\
\hline $\begin{array}{l}\text { Myocardial } \\
\text { infarction }\end{array}$ & $36 / 36(100)$ & $\begin{array}{l}\text { Only primary diagnoses were evaluated. } \\
\qquad N P V=861 / 864(99.7)\end{array}$ & Nilsson [7] & 8114596 & 1994 & MR \\
\hline $\begin{array}{l}\text { Myocardial } \\
\text { infarction }\end{array}$ & 2053/2101 (98) & Patients aged 45 - 70 years in $1992-1994$. & Linnersjö[34] & 11121592 & 2000 & MR \\
\hline Angina Pectoris & 18/19 (95) & $\begin{array}{l}\text { Only primary diagnoses were evaluated. } \\
\qquad N P V=879 / 881\end{array}$ & Nilsson [7] & 8114596 & 1994 & MR \\
\hline Heart failure (HF) & 259/317 (81.7) & $\begin{array}{l}\text { Definition of HF proposed by the } \\
\text { European Society of Cardiology [35]. } \\
\text { Restricting the diagnosis HF to the } \\
\text { primary diagnosis, then 133/140 (95.0\%) } \\
\text { were correct. }\end{array}$ & $\begin{array}{l}\text { Ingelsson } \\
{[36]}\end{array}$ & 15916919 & 2005 & ULSAM \\
\hline Heart failure & 15/17 (88) & $\begin{array}{l}\text { Only primary diagnoses were evaluated. } \\
\qquad N P V=876 / 883(99.2)\end{array}$ & Nilsson [7] & 8114596 & 1994 & MR \\
\hline $\begin{array}{l}\text { Atrial fibrillation } \\
\text { (using ICD-codes } \\
\text { for atrial fibrillation } \\
\text { or atrial flutter) }\end{array}$ & $97 / 100(97)$ & $\begin{array}{l}95 \text { individuals had ECGs consistent with } \\
\text { atrial fibrillation. Two patients had no } \\
\text { ECGs available but were regarded as } \\
\text { having atrial fibrillation on the basis of } \\
\text { medical records. }\end{array}$ & Smith [37] & 19936945 & 2009 & $\begin{array}{l}\mathrm{MR}+ \\
\text { Electrocardiograms } \\
\text { (ECG) }\end{array}$ \\
\hline Non-fatal strokes & $3492 / 5101(68.5)$ & $\begin{array}{l}\text { Patients aged } 25-74 \text { years in } 1985-89 \text {. } \\
\text { Criteria for acute stroke in this study were } \\
\text { based on WHO criteria. }\end{array}$ & $\begin{array}{l}\text { Stegmayr } \\
\text { [38] }\end{array}$ & 1291884 & 1992 & $\begin{array}{l}\text { MONICA-population } \\
\text { based stroke register }\end{array}$ \\
\hline $\begin{array}{l}\text { Stroke/Transient } \\
\text { ischemic Attack }\end{array}$ & 207/210 (98.6) & ULSAM & Wiberg & & $\begin{array}{l}(\mathrm{PC} \\
\mathrm{Feb} \\
12)\end{array}$ & ULSAM \\
\hline $\begin{array}{l}\text { Gestational } \\
\text { hypertension }\end{array}$ & 108/111 (97.3) & & Zetterström & & $\begin{array}{l}\text { (PC, } \\
\text { March } \\
\text { 3) }\end{array}$ & MR \\
\hline $\begin{array}{c}\text { Gestational } \\
\text { hypertension }\end{array}$ & 97/115 (84.3) & & Ros [39] & 9620050 & 1998 & MR \\
\hline $\begin{array}{l}\text { Vascular } \\
\text { interventions (for } \\
\text { lower limb } \\
\text { ischemia) }\end{array}$ & $545 / 546(99.8)$ & & $\begin{array}{l}\text { Hultgren } \\
{[40]}\end{array}$ & 11170873 & 2001 & MR \\
\hline \multicolumn{7}{|c|}{ Autoimmune/immune-mediated diseases } \\
\hline $\begin{array}{l}\text { Rheumatoid } \\
\text { arthritis (RA) }\end{array}$ & $489 / 510(95.9)$ & $\begin{array}{c}\text { Malmö, Sweden, 1990-1994. According to } \\
\text { the RA criteria of the American College of } \\
\text { Rheumatology [41]. }\end{array}$ & $\begin{array}{l}\text { Turesson } \\
{[42]}\end{array}$ & 10461483 & 1999 & MR \\
\hline $\begin{array}{l}\text { Rheumatoid } \\
\text { arthritis }\end{array}$ & $\begin{array}{c}\text { Without lymphoma: } \\
\text { 440/505 (87.1) } \\
\text { With lymphoma: } 386 / \\
413 \text { (93.5) }\end{array}$ & $\begin{array}{l}\text { In } 40 \text { of the } 386 \text { cases with lymphoma, } \\
\text { medical records did not include enough } \\
\text { information to evaluate whether the RA } \\
\text { criteria of the American College of } \\
\text { Rheumatology were fulfilled but all } \\
\text { available information supported the } \\
\text { diagnosis of RA }\end{array}$ & $\begin{array}{l}\text { Baecklund } \\
\text { [22] }\end{array}$ & 16508929 & 2006 & MR \\
\hline $\begin{array}{l}\text { Wegener's } \\
\text { granulomatosis }\end{array}$ & $68 / 78(87)$ & $\begin{array}{c}\text { American College of Rheumatology } \\
\text { diagnostic criteria [43] }\end{array}$ & Knight [12] & 12115591 & 2002 & MR \\
\hline Celiac disease & $\begin{array}{l}66 / 77 \text { (86) of patients } \\
\text { with later lymphoma }\end{array}$ & $\begin{array}{l}\text { Only in } 8 \text { patients could celiac disease be } \\
\text { ruled out. In } 3 \text { patients, the chart reviews } \\
\text { were consistent with possible celiac } \\
\text { disease. }\end{array}$ & $\begin{array}{l}\text { Ekström- } \\
\text { Smedby [44] }\end{array}$ & 15591504 & 2005 & MR \\
\hline $\begin{array}{l}\text { Primary } \\
\text { adrenocortical } \\
\text { insufficiency }\end{array}$ & 105/133 (78.9) & & Bensing [45] & 18727712 & 2008 & $\begin{array}{l}\text { Patients tested positive } \\
\text { for } 21-\mathrm{OH} \\
\text { autoantibodies }\end{array}$ \\
\hline $\begin{array}{l}\text { Diabetes mellitus } \\
\text { (type } 1 \text { and } 2)^{*}\end{array}$ & 22/28 (79) & $\begin{array}{l}\text { Only primary diagnoses were evaluated. } \\
\qquad N P V=872 / 872(100)\end{array}$ & Nilsson [7] & 8114596 & 1994 & MR \\
\hline $\begin{array}{l}\text { Both diabetes (type } \\
1 \text { or } 2 \text { ) and foot } \\
\text { ulcer* }\end{array}$ & $\begin{array}{l}235 / 236(99.6) \\
\text { admissions were } \\
\text { correct with regards } \\
\text { to ICD-coding }\end{array}$ & $\begin{array}{l}117 \text { patients with deep foot infections and } \\
\text { type } 1 \text { or } 2 \text { diabetes, who had been } \\
\text { referred to a multidisciplinary foot-care } \\
\text { team at Lund University Hospital. }\end{array}$ & $\begin{array}{l}\text { Ragnarson- } \\
\text { Tennvall [46] }\end{array}$ & 11123504 & 2000 & MR \\
\hline
\end{tabular}


Table 3 Validation of diagnoses in the Swedish Inpatient Register by Positive Predictive Values (PPVs) (Continued)

\begin{tabular}{|c|c|c|c|c|c|c|}
\hline $\begin{array}{l}\text { Inflammatory } \\
\text { bowel disease (IBD) }\end{array}$ & $4778 / 6440(74)$ & $\begin{array}{l}\text { 1965-1983. } \\
\text { Due to the ICD-classification used at this } \\
\text { time, ulcerative colitis could not be } \\
\text { distinguished from Crohn's disease, and } \\
\text { therefore "overall IBD" was evaluated }\end{array}$ & Ekbom [47] & 1985033 & 1991 & $\begin{array}{l}\mathrm{MR}+\text { histopathological } \\
\text { reviews }\end{array}$ \\
\hline \multicolumn{7}{|c|}{ Psychiatric disease and neurology } \\
\hline Schizophrenia & $94 / 100$ (94.9) & $\begin{array}{c}\text { Review of medical records with structured } \\
\text { diagnostic interviews }\end{array}$ & Ekholm [48] & 16316898 & 2005 & MR \\
\hline Schizophrenia & 78/91 (85.7) & $\begin{array}{l}\text { Individuals born 1973-77. } \\
\text { DSM-IV criteria for schizophrenia } \\
\text { syndrome }\end{array}$ & Dalman [49] & 12395142 & 2002 & MR \\
\hline Schizophrenia & 106/111 (95.5) & $\begin{array}{c}\text { Review of } 121 \text { consecutive cases in one } \\
\text { city using a structured DSM-IV checklist, } \\
111 \text { records obtained }\end{array}$ & $\begin{array}{l}\text { Hultman } \\
{[50]}\end{array}$ & 16863597 & 2006 & MR \\
\hline $\begin{array}{l}\text { Schizophrenia, } \\
\text { schizophreniform } \\
\text { disorder or } \\
\text { schizoaffective } \\
\text { disorder }\end{array}$ & $94 / 168(56)$ & $\begin{array}{l}\text { Primary diagnoses that fulfilled DSM-IV } \\
\text { criteria (OPCRIT algorithm) }\end{array}$ & Reutfors [51] & - & 2009 & MR \\
\hline Schizophrenia † & $\begin{array}{l}78 / 104(75.0) \\
\text { to } \\
85 / 104(81.7)\end{array}$ & $\begin{array}{l}104 \text { patients discharged in } 1971 \text { with a } \\
\text { diagnosis of schizophrenia. DSMIII-criteria } \\
\text { were used for this validation. From } \\
\text { Stockholm County IPR. A strict review } \\
\text { found a PPV of } 75 \% \text {. This figure increased } \\
\text { to } 85 \% \text { when some lack of information } \\
\text { was accepted (less strict criteria). }\end{array}$ & $\begin{array}{l}\text { Kristjansson } \\
\text { [52] }\end{array}$ & - & 1987 & MR \\
\hline Schizophrenia & $\begin{array}{c}\text { (Kappa }=0.37 \\
\text { correlating to an } \\
\text { agreement rate of } \\
68 \%)\end{array}$ & $\begin{array}{l}\text { All individuals with a diagnosis of } \\
\text { schizophrenia in the IPR and who had an } \\
\text { inpatient forensic psychiatric assessment } \\
\text { using a national register of all such } \\
\text { evaluations from 1988-2000 ( } \mathrm{n}=1638) \text {. }\end{array}$ & Fazel [25] & 19454640 & 2009 & $\begin{array}{l}\text { Forensic psychiatric } \\
\text { assessment }\end{array}$ \\
\hline Schizophrenia & $34 / 44(77 \%)$ & & $\begin{array}{l}\text { Bergman } \\
{[53]}\end{array}$ & - & 1999 & $\begin{array}{l}\text { Four-week- inpatient } \\
\text { assessment in forensic } \\
\text { psychiatry department }\end{array}$ \\
\hline Alzheimer & $54 / 75(72)$ & & $\operatorname{Jin}[54]$ & 15326258 & 2004 & $\begin{array}{l}\text { Clinical work-up } \\
\text { following phone } \\
\text { interview }\end{array}$ \\
\hline $\begin{array}{l}\text { Personality } \\
\text { disorders }\end{array}$ & $37 / 40(92)$ & $\begin{array}{l}\text { Random sample of } 40 \text { individuals out of } \\
401 \text { violent offenders with personality } \\
\text { disorders from a longitudinal study }\end{array}$ & Grann [55] & - & 1998 & MR \\
\hline $\begin{array}{l}\text { Personality } \\
\text { disorders }\end{array}$ & $30 / 55(55 \%)$ & & $\begin{array}{l}\text { Bergman } \\
{[53]}\end{array}$ & - & 1999 & $\begin{array}{l}\text { Four-week- inpatient } \\
\text { assessment in forensic } \\
\text { psychiatry department }\end{array}$ \\
\hline $\begin{array}{l}\text { Guillain-Barré } \\
\text { Syndrome (GBS) }\end{array}$ & 69/83 (83) & $\begin{array}{l}\text { 83\% of patients fulfilled the National } \\
\text { Institute of Neurological and } \\
\text { Communicative Disorders and Stroke } \\
\text { criteria for GBS [56]. PPV of first primary } \\
\text { diagnosis with GBS was } 84 \% \text {; and for } \\
\text { secondary diagnosis } 75 \% \text {. }\end{array}$ & Jiang [57] & 7785420 & 1995 & MR \\
\hline $\begin{array}{l}\text { Herpes simplex } \\
\text { encephalit }\end{array}$ & 223/638 (35.0) & $1990-2001$ & $\begin{array}{l}\text { Hjalmarsson } \\
{[58]}\end{array}$ & 17806053 & 2007 & $\begin{array}{l}\text { Laboratory data } \\
\text { (positive finding of } \\
\text { HSV-1) }\end{array}$ \\
\hline \multicolumn{7}{|c|}{ Trauma and fractures } \\
\hline Brain concussion & 18/18 (100) & $\begin{array}{l}\text { Only primary diagnoses were evaluated. } \\
\qquad N P V=880 / 882\end{array}$ & Nilsson [7] & 8114596 & 1994 & MR \\
\hline Hip fracture & $21 / 22(95)$ & $\begin{array}{l}\text { Only primary diagnoses were evaluated. } \\
\qquad N P V=877 / 878 \text { (99.9) }\end{array}$ & Nilsson [7] & 8114596 & 1994 & MR \\
\hline Hip fracture & 2556/2597 (98.4) & $\begin{array}{c}\text { Cases derived both from IPR and } \\
\text { operation registers. }\end{array}$ & $\begin{array}{l}\text { Michaelsson } \\
\text { [59] }\end{array}$ & 9632404 & 1998 & MR \\
\hline Injuries & 1299/1370 (94.8) & Injury code was correct at 3-digit-level. & Gedeborg & - & $\begin{array}{l}(\mathrm{PC} \\
\text { Feb 3) }\end{array}$ & MR \\
\hline
\end{tabular}


Table 3 Validation of diagnoses in the Swedish Inpatient Register by Positive Predictive Values (PPVs) (Continued)

\begin{tabular}{|c|c|c|c|c|c|c|}
\hline $\begin{array}{l}\text { Major amputations } \\
\quad \text { (leg and arm) }\end{array}$ & 610/624 (97.8) & $\begin{array}{l}\text { Unique number of amputations was } 610 \\
\text { in } 624 \text { patients. }\end{array}$ & Malmstedt & & $\begin{array}{l}(P C, \\
\text { Feb } \\
24)\end{array}$ & MR \\
\hline Appendicitist & $1661 / 1840(90.3)$ & $\begin{array}{l}\text { Performed in the Jönköping county. } \\
\text { Incidental appendectomies were excluded. } \\
\text { The IPR overestimated the prevalence of } \\
\text { appendicitis with } 6 \% \text {. The negative } \\
\text { predictive value of appendicitis was } 94.0 \% \\
\text { and the accuracy } 91.3 \% \dagger\end{array}$ & $\begin{array}{l}\text { Andersson } \\
\text { [60] }\end{array}$ & 8298378 & 1994 & $\begin{array}{l}\text { Histological } \\
\text { examination of excised } \\
\text { tissue (in patients } \\
\text { undergoing } \\
\text { appendectomy) }\end{array}$ \\
\hline Inguinal hernia & 17/18 (94) & $\begin{array}{l}\text { Only primary diagnoses were evaluated. } \\
\qquad N P V=882 / 882(100)\end{array}$ & Nilsson [7] & 8114596 & 1994 & MR \\
\hline \multicolumn{7}{|l|}{ Other disorders } \\
\hline Achalasia & 67/83 (81) & & $\begin{array}{l}\text { Zendehdel } \\
\text { [61] }\end{array}$ & 17488250 & 2007 & MR \\
\hline $\begin{array}{l}\text { Prostate } \\
\text { hyperplasia }\end{array}$ & $14 / 14(100)$ & $\begin{array}{l}\text { Only primary diagnoses were evaluated. } \\
\qquad N P V=882 / 886(99.5)\end{array}$ & Nilsson [7] & 8114596 & 1994 & MR \\
\hline Asthma & 14/15 (93) & $\begin{array}{l}\text { Only primary diagnoses were evaluated. } \\
\qquad N P V=885 / 885(100)\end{array}$ & Nilsson [7] & 8114596 & 1994 & MR \\
\hline $\begin{array}{l}\text { Abdominal pain } \\
\text { (observation for } \\
\text { abdominal pain) }\end{array}$ & 33/37 (89) & $\begin{array}{l}\text { Only primary diagnoses were evaluated. } \\
\qquad N P V=860 / 863(99.7)\end{array}$ & Nilsson [7] & 8114596 & 1994 & MR \\
\hline Preeclampsia & 137/148 (92.6) & & Ros [39] & 9620050 & 1998 & MR \\
\hline Endometriosis & $\begin{array}{l}\text { Without ovarial } \\
\text { cancer: } 615 / 628 \\
\text { ( } 97.9 \% \text { correct). } \\
\text { With ovarial cancer: } \\
\text { 220/225 (97.8\% } \\
\text { correct) }\end{array}$ & & Melin & - & $\begin{array}{l}\text { (PC, } \\
\text { Feb 3) }\end{array}$ & MR \\
\hline Foot ulcer (only) & $\begin{array}{l}249 / 250(99.6) \\
\text { admissions to hospital } \\
\text { were correct with } \\
\text { regards to ICD-coding }\end{array}$ & $\begin{array}{l}\text { Based on } 117 \text { patients with deep foot } \\
\text { infections and type } 1 \text { or } 2 \text { diabetes, } \\
\text { referred to multidisciplinary foot-care } \\
\text { team. Specificity for foot ulcers and } \\
\text { concomitant diabetes was } 98 \% \text {. }\end{array}$ & $\begin{array}{l}\text { Ragnarson- } \\
\text { Tennvall [46] }\end{array}$ & 11123504 & 2000 & MR \\
\hline $\begin{array}{l}\text { Connective tissue } \\
\text { disease (CTD) }\end{array}$ & 71/91 (78\%) & $\begin{array}{l}\text { In this study CTD included rheumatoid } \\
\text { arthritis, systemic lupus erythemathosus, } \\
\text { sclerodermia, Sjögren's syndrome, } \\
\text { dermatomyositis, polymyositis etc. }\end{array}$ & Nyren [62] & 9492663 & & MR \\
\hline Acute pancreatitis & 695/602 (98.8) & $\begin{array}{l}\text { Among } 602 \text { patients with a primary or } \\
\text { secondary diagnosis of acute pancreatitis } \\
\text { in the IPR. } 84.0 \% \text { had a definitive acute } \\
\text { pancreatitis and another } 14.8 \% \text { a probable } \\
\text { acute pancreatitis. }\end{array}$ & Lindblad & & $\begin{array}{l}(\mathrm{PC} \\
\text { Feb 6) }\end{array}$ & $\begin{array}{l}\text { MR + laboratory tests } \\
\text { and radiological } \\
\text { imaging }\end{array}$ \\
\hline
\end{tabular}

PC, Personal communication: All personal communications took place in 2010 (exact date is listed in the table).

CDT, Connective tissue disease. GBS, Guillain-Barré Syndrome; HF, Heart Failure, IBD, Inflammatory bowel disease. IPR, Inpatient Register.

MR, compared with Medical Records (patient charts).

PPV, Positive Predictive Value.

NPV, Negative Predictive Value.

ULSAM, Uppsala Longitudinal Study of Adult Men) cohort.

*From ICD-7 through ICD-9, no distinction was made between type 1 and type 2 diabetes. For practical reasons "diabetes" has been listed as an autoimmune disorder.

† These studies took place when the county in question did not yet report inpatient data to the IPR, but results are deemed valid for the IPR.

identified through the IPR, but only 1.09 in patients identified through regional clinic registers and 1.15 in those identified through outpatient data sources [30]. Some evidence suggests that patients with a certain disorder identified through the IPR may suffer from more intense disease than the average patient and be at higher risk of complications than patients identified outside the IPR (a phenomenon sometimes called Berkson's bias [31]).
Another issue that deserves attention is that the first recorded admission with a disorder is not always equal to the incident admission. According to patient chart reviews, 1 in 3 patients with a hospital admission for stroke had had an earlier stroke (L. Olai, personal communication, Feb 4, 2010). In an effort to separate incident admissions from readmissions some authors have suggested using prediction models combining information from current and previous records in the IPR [32]. 
Table 4 Validation of diagnoses in the Swedish Inpatient Register by sensitivity

\begin{tabular}{|c|c|c|c|c|c|c|}
\hline Diagnosis & $\begin{array}{c}\text { Proportion identified } \\
\text { through the IPR (\%) } \\
\text { (sensitivity) } \\
\end{array}$ & Comment & $\begin{array}{l}\text { Main } \\
\text { Author }\end{array}$ & $\begin{array}{l}\text { PubMed } \\
\text { ID }\end{array}$ & Year & Gold Standard (Reference) \\
\hline \multicolumn{7}{|c|}{ Cardiovascular disease } \\
\hline $\begin{array}{l}\text { Myocardial } \\
\text { Infarction (MI) }\end{array}$ & $54 / 59(91.5)$ & $\begin{array}{l}\text { Cross-sectional, 1-year } \\
\text { retrospective study. } \geq 20 \text { year-olds } \\
\text { from Degerfors area. }\end{array}$ & Elo [14] & 19084244 & 2009 & $\begin{array}{l}\text { Data were obtained from IPR, } \\
\text { hospital-based outpatient care } \\
\text { and primary health care }\end{array}$ \\
\hline $\begin{array}{l}\text { Myocardial } \\
\text { infarction }\end{array}$ & $99 / 128(77)$ & & Merlo [63] & 10870938 & 2000 & Men born 1914 \\
\hline $\begin{array}{l}\text { Myocardial } \\
\text { infarction }\end{array}$ & 113/144 (79) & & Merlo [63] & 10870938 & 2000 & $\begin{array}{l}\text { The Skaraborg Hypertension } \\
\text { Study }\end{array}$ \\
\hline $\begin{array}{l}\text { Myocardial } \\
\text { Infarction }\end{array}$ & $3201 / 4148(77.2)$ & $\begin{array}{l}\text { The researchers identified all Mls } \\
\text { in Stockholm county in } 1973 \\
\text { through the local IPR and the } \\
\text { national Cause of Death Register } \\
\text { (restricted to individuals living in } \\
\text { Stockholm). }\end{array}$ & $\begin{array}{l}\text { Ahlbom } \\
\text { [64] }\end{array}$ & 721364 & 1978 & $\begin{array}{c}\text { Swedish Cause of Death } \\
\text { Register }\end{array}$ \\
\hline $\begin{array}{l}\text { Myocardial } \\
\text { infarction }\end{array}$ & $\begin{array}{l}\text { 4746/5832 (81.4) of MI } \\
\text { cases in community } \\
\text { registers were found in IPR } \\
\text { or the Cause of Death } \\
\text { Register. }\end{array}$ & $\begin{array}{l}\text { IPR and Cause of Death Register } \\
\text { data from 1972-1981 for regions } \\
\text { with IPR registers at the time. } \\
81 \% \text { of cases in community } \\
\text { registers were found in IPR or } \\
\text { Cause of Death Register. } \\
\text { Meanwhile } 85 \% \text { of cases in IPR } \\
\text { and the Cause of Death Register } \\
\text { were found in Community } \\
\text { registers (disregarding non- } \\
\text { matching fatal cases). }\end{array}$ & $\begin{array}{l}\text { Hammar } \\
{[65]}\end{array}$ & 2066207 & 1991 & $\begin{array}{l}\text { Community registers with } \\
\text { myocardial infarctions }\end{array}$ \\
\hline Angina Pectoris & 86/196 (43.9) & $\begin{array}{l}\text { Cross-sectional, } 1 \text {-year } \\
\text { retrospective study. } \geq 20 \text { year-olds } \\
\text { from Degerfors area. }\end{array}$ & Elo [14] & 19084244 & 2009 & $\begin{array}{l}\text { Data were obtained from IPR, } \\
\text { hospital-based outpatient care } \\
\text { and primary health care }\end{array}$ \\
\hline $\begin{array}{l}\text { Acute coronary } \\
\text { syndrome (Ml } \\
\text { or unstable } \\
\text { angina } \\
\text { pectoris) }\end{array}$ & $\begin{array}{l}\text { IPR from emergency } \\
\text { department missed } 2 \% \text { of } \\
218 \text { patients with acute } \\
\text { coronary syndrome. }\end{array}$ & $\begin{array}{l}\text { Discharge diagnoses from } \\
\text { emergency department, Lund } \\
\text { University Hospital. }\end{array}$ & $\begin{array}{l}\text { Forberg } \\
\text { [66] }\end{array}$ & 18804783 & 2009 & $\begin{array}{l}\text { MR. The study evaluates } \\
\text { different methods to identify } \\
\text { acute coronary syndrome in } \\
\text { patients, using information not } \\
\text { available in the IPR (e.g. ECG } \\
\text { measurements). }\end{array}$ \\
\hline $\begin{array}{l}\text { Non-specified } \\
\text { ischemic heart } \\
\text { disease }\end{array}$ & $44 / 206(21.4)$ & $\begin{array}{l}\text { Cross-sectional, } 1 \text {-year } \\
\text { retrospective study. } \geq 20 \text { year-olds } \\
\text { from Degerfors area. }\end{array}$ & Elo [14] & 19084244 & 2009 & $\begin{array}{l}\text { Data were obtained from IPR, } \\
\text { hospital-based outpatient care } \\
\text { and primary health care }\end{array}$ \\
\hline $\begin{array}{l}\text { Stroke (non- } \\
\text { subarachnoidal } \\
\text { hemorrhage) }\end{array}$ & $318 / 377(84.4)$ & $\begin{array}{c}\text { Data from a local stroke } \\
\text { incidence study at the Örebro } \\
\text { University Hospital. }\end{array}$ & Appelros & - & $\begin{array}{l}(\mathrm{PC}, \\
\mathrm{Feb} \\
22)\end{array}$ & Local stroke incidence study \\
\hline $\begin{array}{l}\text { Non-fatal } \\
\text { strokes }\end{array}$ & $\begin{array}{c}\text { 3492/3732 (93.6) of all } \\
\text { cases } \\
\text { 3492/3562 (98.0) of } \\
\text { estimated hospital cases }\end{array}$ & $\begin{array}{l}\text { Patients aged } 25-74 \text { years in } \\
\text { 1985-89. Criteria for acute stroke } \\
\text { from MONICA study were } \\
\text { comparable to WHO criteria. }\end{array}$ & $\begin{array}{l}\text { Stegmayr } \\
{[38]}\end{array}$ & 1291884 & 1992 & $\begin{array}{l}\text { MONICA-population based } \\
\text { stroke register }\end{array}$ \\
\hline Stroke & $75 / 79(95)$ & & Merlo [63] & 10870938 & 2000 & $\begin{array}{l}\text { The Skaraborg Hypertension } \\
\text { Study }\end{array}$ \\
\hline Stroke & 76/81 (94) & & Merlo [63] & 10870938 & 2000 & "Men born 1914" \\
\hline Stroke & $384 / 456(84.2)$ & $\begin{array}{l}\text { First-time stroke. Restricted to the } \\
\text { Lund county. }\end{array}$ & $\begin{array}{l}\text { Hallström } \\
{[67]}\end{array}$ & 17156265 & 2007 & * \\
\hline $\begin{array}{l}\text { Stroke/ } \\
\text { Transient } \\
\text { ischemic A. }\end{array}$ & $217 / 232(93.5)$ & ULSAM. & Wiberg & - & $\begin{array}{l}(\mathrm{PC} \\
\mathrm{Feb} \\
12)\end{array}$ & ULSAM \\
\hline Hypertension & $5,886 / 42,796(13.7)$ & $\begin{array}{l}\text { IPR data from the county } \\
\text { Östergötland. }\end{array}$ & Wiréhn [68] & 17786807 & 2007 & $\begin{array}{l}\text { County registers of primary } \\
\text { health care, outpatient hospital } \\
\text { care and inpatient care }\end{array}$ \\
\hline Hypertension & 74/838 (8.8) & $\begin{array}{l}\text { Cross-sectional, 1-year } \\
\text { retrospective study. } \geq 20 \text { year-olds } \\
\text { from Degerfors area. }\end{array}$ & Elo $[14]$ & 19084244 & 2009 & $\begin{array}{l}\text { Data were obtained from IPR, } \\
\text { hospital-based outpatient care } \\
\text { and primary health care }\end{array}$ \\
\hline $\begin{array}{l}\text { Gestational } \\
\text { hypertension }\end{array}$ & 108/166 (65.1) & & Zetterström & - & $\begin{array}{l}\text { (PC, } \\
\text { March } \\
\text { 3) }\end{array}$ & $\begin{array}{c}\text { All pregnant women in Sweden } \\
\text { have their blood pressure } \\
\text { examined. }\end{array}$ \\
\hline
\end{tabular}


Table 4 Validation of diagnoses in the Swedish Inpatient Register by sensitivity (Continued)

\begin{tabular}{|c|c|c|c|c|c|c|}
\hline Lipid disorders & 19/186 (10.2) & $\begin{array}{l}\text { Cross-sectional, 1-year } \\
\text { retrospective study. } \geq 20 \text { year-olds } \\
\text { from Degerfors area. }\end{array}$ & Elo [14] & 19084244 & 2009 & $\begin{array}{l}\text { Data were obtained from IPR, } \\
\text { hospital-based outpatient care } \\
\text { and primary health care }\end{array}$ \\
\hline \multicolumn{7}{|c|}{ Autoimmune/immune-mediated diseases } \\
\hline $\begin{array}{l}\text { Rheumatoid } \\
\text { arthritis (RA) }\end{array}$ & $489 / 1150(42.5)$ & $\begin{array}{c}\text { Malmö, Sweden, 1990-1994. } \\
\text { According to the RA criteria of } \\
\text { the American College of } \\
\text { Rheumatology [41]. }\end{array}$ & $\begin{array}{l}\text { Turesson } \\
{[42]}\end{array}$ & 10461483 & 1999 & $\begin{array}{c}\text { Data from all rheumatologists } \\
\text { and general practictioners in } \\
\text { Malmö city, } 1997\end{array}$ \\
\hline $\begin{array}{c}\text { Diabetes, type } \\
1 \text { and } 2^{*}\end{array}$ & $92 / 394(23.3)$ & $\begin{array}{l}\text { Cross-sectional, } 1 \text {-year } \\
\text { retrospective study. } \geq 20 \text { year-olds } \\
\text { from Degerfors area. }\end{array}$ & Elo [14] & 19084244 & 2009 & $\begin{array}{l}\text { Data were obtained from IPR, } \\
\text { hospital-based outpatient care } \\
\text { and primary health care }\end{array}$ \\
\hline $\begin{array}{c}\text { Type } 1 \text { and } \\
\text { type } 2 \text { diabetes } \\
\text { mellitus* }\end{array}$ & $\begin{array}{l}\text { 349/436 (80.0) patients with } \\
\text { diabetes in "source 1" } \\
\text { could be identified in the } \\
\text { IPR }\end{array}$ & $\begin{array}{l}\text { The researchers evaluated the } \\
\text { presence of type } 1 \text { or type } 2 \\
\text { diabetes among patients with } \\
\text { atrial fibrillations at the }\end{array}$ & Friberg & - & $\begin{array}{l}(\mathrm{PC} \\
\text { Feb 8) }\end{array}$ & $\begin{array}{c}\text { MR + biochemistry data }+ \text { data } \\
\text { on insulin or other medication } \\
\text { against diabetes }\end{array}$ \\
\hline
\end{tabular}

Type 1 and type 2 diabetes mellitus*

Both type $1 / 2 \quad 235 / 280(83.9)$ admissions diabetes and could be identified through foot ulcer the IPR

\section{Infectious disease \\ CNS infection \\ in intensive \\ ICD-9: 21/22 (95.4) \\ care \\ Pneumonia in \\ ICD-9: 89/185 (48.1) \\ intensive care \\ ICD-10: 116/221 (52.5)}

Sepsis in intensive care

ICD-9: 85/186 (45.7)

ICD-10: 94/179 (52.5)

Tuberculosis

$12 / 15(80)$

\section{Other disorders}

$\begin{array}{cc}\begin{array}{c}\text { Carotid, } \\ \text { infrainguinal }\end{array} & 10,861 / 11,638 \text { (93.3) of } \\ \text { bypass and } & \text { patients identified through } \\ \text { aortic } & \text { kärlregistret) or the IPR } \\ \text { aneurysm } & \text { could be identified in the } \\ \text { (AAA) } & \text { IPR } \\ \text { procedures } & \end{array}$

Asthma $\quad 1,377 / 18,451(7.5)$

Södersjukhuset Hospital. All but 8 patients in this validation had type 2 diabetes.

IPR data from the county Östergötland.

Based on 117 patients with deep foot infections and type 1 or 2 diabetes, referred to multidisciplinary foot-care team. Specificity for foot ulcers and concomitant diabetes was $98 \%$.

Wiréhn [68] $17786807 \quad 2007$

Ragnarson- 111235042000 Tennvall [46]

Specificity was $99.6 \%$ (ICD-9) and 99.7\% (ICD-10). IPR data obtained through both primary and secondary diagnoses.

Specificity was 95.9\% (ICD-9) and Gedeborg 172081212007 95.8\% (ICD-10). IPR data obtained [69] through both main and secondary diagnoses.

Using only primary diagnoses for pneumonia the specificity increased slightly but the sensitivity decreased to $31.2 \%$ and $38.2 \%$ respectively.

Specificity was 97.5\% (ICD-9) and Gedeborg 172081212007

92.6\% (ICD-10). IPR data obtained [69] through both main and secondary diagnoses.

Evaluation in patients with concomitant rheumatoid arthritis

Askling [70] $15986370 \quad 2005$

(Swedvasc) started in 1987 and became nationwide 1994. In the paper by Troëng et al data on infraingunal and carotid bypass originated from 5 years (20002004), while data on aortic aneurysms originated from 1 year (2006). Divided the sensitivity figures were: Carotid 96.8\%; Infrainguinal $92.3 \%$ and aortic aneurysm 88.9\%.

IPR data from the county Östergötland.
Troëng [15] 188519202008 The Swedish Vascular Register And by

(Swedvasc)
County registers of primary health care, outpatient hospital care and inpatient care $M R$
ICU database diagnoses as reference, with inclusion in sepsis trials (IST) as secondary reference

MR 


\begin{tabular}{|c|c|c|c|c|c|c|}
\hline Dementia & 23/87 (26) & $\begin{array}{l}\text { Participants originated from the } \\
\text { study "Aging in women and } \\
\text { men: a longitudinal study of } \\
\text { gender differences in health } \\
\text { behaviour and health among the } \\
\text { elderly (as part of the Swedish } \\
\text { Twin Register). The specificity for } \\
\text { dementia was } 97 \% \text { (399/411) }\end{array}$ & Dahl [71] & 18007116 & & $\mathrm{MR}+$ memory test scores etc. \\
\hline Dementia & $\begin{array}{c}\text { 41.3\% for prevalent cases } \\
\text { and } 42.3 \% \text { for incident } \\
\text { cases. }\end{array}$ & $\begin{array}{l}\text { Participants originated from the } \\
\text { study "Aging in women and } \\
\text { men: a longitudinal study of } \\
\text { gender differences in health } \\
\text { behaviour and health among the } \\
\text { elderly (as part of the Swedish } \\
\text { Twin Register). The specificity for } \\
\text { dementia was } 97 \% \text { (399/411) }\end{array}$ & Rizutto & & $\begin{array}{l}(\mathrm{PC}, \\
\text { May } \\
14)\end{array}$ & $\begin{array}{l}\text { Comparison between cases } \\
\text { detected in IPR with cases } \\
\text { derived from the Kungsholmen } \\
\text { (KP) and SNAC-K Projects [72] }\end{array}$ \\
\hline $\begin{array}{l}\text { Foot ulcer } \\
\text { (only) }\end{array}$ & $\begin{array}{l}249 / 280(88.9 \%) \text { of } \\
\text { admissions could be } \\
\text { identified through the IPR }\end{array}$ & $\begin{array}{c}\text { Based on } 117 \text { patients with deep } \\
\text { foot infections and type } 1 \text { or } 2 \\
\text { diabetes, referred to } \\
\text { multidisciplinary foot-care team. }\end{array}$ & $\begin{array}{l}\text { Ragnarson- } \\
\text { Tennvall } \\
{[46]}\end{array}$ & 11123504 & 2000 & $M R$ \\
\hline $\begin{array}{l}\text { Chronic } \\
\text { obstructive } \\
\text { pulmonary } \\
\text { disease }\end{array}$ & $1,290 / 4,812(26.8)$ & $\begin{array}{c}\text { IPR data from the county } \\
\text { Östergötland. }\end{array}$ & Wiréhn [68] & 17786807 & 2007 & $\begin{array}{c}\text { County registers of primary } \\
\text { health care, outpatient hospital } \\
\text { care and inpatient care }\end{array}$ \\
\hline
\end{tabular}

PC, Personal communication: All personal communications took place in 2010 (exact date is listed in the table).

ICU, Intensive Care Unit. MI, Myocardial Infarction. MR, compared with Medical Records (patient charts). RA, Rheumatoid arthritis.

ULSAM, Uppsala Longitudinal Study of Adult Men) cohort.

*Data from all departments at the Lund Hospital including the emergency unit, general practitioners, community nurses, physicians at the Neurology department, autopsy registers, Forensic department, computerized searches of outpatient medical records

It should be noted that the Swedish ICD system does contain a number of codes representing late effects of disease, such as ICD code I69 ("late effects of cerebrovascular disease").

A number of non-medical factors influence the coding of hospital discharges. Although originally used to collect data on health care use, today the IPR coding is also used as the basis for management and financing. Some hospitals have introduced compulsory use of certain secondary codes (when such codes apply) because these codes generate extra funding (e.g., a secondary code of diabetes mellitus is "valuable"). Further, international research suggests that the coding pattern may differ between hospitals and general practice [33]. Financial incitements have therefore led to a "diagnostic drift" in which more secondary diagnoses are listed [27] and where it is financially more rewarding to assign a patient a severe primary diagnosis than a severe secondary diagnosis (e.g., type 1 diabetes is more "valuable" as a primary diagnosis than as a secondary diagnosis). The effects of financial incitements on ICD coding have probably been underestimated and are likely to have changed the epidemiological pattern. A standardized behaviour of assigning ICD codes is therefore of importance for all stakeholders, including the Swedish state [27].

Despite the extensive scope of the IPR, there is still a need for additional variables (Additional file 3), including laterality, index admission, earlier comorbidity and risk factors (e.g., smoking).

\section{Conclusion}

In conclusion, the Swedish IPR is a valuable resource for large-scale register-based research. A number of diagnoses have already been validated by the NBHW and by individual researchers. Current data suggest that the overall PPV of diagnoses in the register is about $85-95 \%$.

\section{Additional material}

Additional file 1: Detailed description of the laws and regulations governing the Swedish Inpatient Register. Please see Title.

Additional file 2: Population data used to construct Figures 2 and 3. Population of Swedish Counties in1960 and 1990.

Additional file 3: Variables that could potentially add value to the Inpatient Register. This file lists a number of variables that could be added to the Inpatient Register.

\section{List of abbreviations}

IPR: Swedish Inpatient Register (Slutenvårdsregistret); MI: Myocardial infarction; NBHW: National Board of Health and Welfare (Socialstyrelsen); PIN: Personal Identity Number.

\section{Acknowledgements}

We would like to thank all the researchers contributing to this paper. Special thanks go to Björn Smedby and Paul Blomqvist for their generous advice and to the University Library of the Karolinska Institutet for assistance. 
The writing of this paper was made possible by a grant from the Swedish Society of Medicine, funding the salary of the main author, Jonas F Ludvigsson. The paper was written on behalf of SVEP - The Swedish Society of Epidemiology.

\section{Author details}

'Department of Paediatrics, Örebro University Hospital, Sweden. ${ }^{2}$ Clinical Epidemiology Unit, Department of Medicine, Karolinska University Hospital, Karolinska Institutet, Sweden. ${ }^{3}$ Section of Occupational and Environmental Medicine, University of Gothenburg, Sweden. ${ }^{4}$ Institute of Environmental Medicine, Karolinska Institutet, Sweden. ${ }^{5}$ Research Unit, Jämtland County, Sweden. ${ }^{6}$ Department of Public Health and Clinical Medicine, Umeå University, Sweden. ${ }^{7}$ Department of Statistics and Analyses, National Board of Health and Welfare, Stockholm, Sweden.

\section{Authors' contributions}

JFL designed the study, collected the data, and wrote the first draft of the paper. JFL, EA, AE, MF, JLK, CR and POO examined the papers that were used when examining the validity of the Swedish Inpatient Register. All authors contributed to the interpretation of the results. All authors read and approved the final manuscript.

\section{Competing interests}

The authors declare that they have no competing interests.

The funding organizations played no role in the design or conduct of the study, in the collection, management, analysis, or interpretation of the data, and did not participate in preparation, review, or approval of the manuscript.

Received: 2 September 2010 Accepted: 9 June 2011

Published: 9 June 2011

\section{References}

1. Smedby B, Schiøler G: Health Classifications in the Nordic Countries. Historic development in a national and international perspective 2006. Book Health Classifications in the Nordic Countries. Historic development in a national and international perspective 2006 (Editor ed. ^eds.) City: Nordisk Medicinalstatistisk Komite; 2006.

2. Forsberg L, Rydh H, Jacobsson A, Nyqvist K, Heurgren M: Kvalitet och innehåll i patientregistret. Utskrivningar från slutenvården 1964-2007 och besök i specialiserad öppenvård (exklusive primärvårdsbesök) 19972007. (Quality and content of the Patient Register)(2009-125-15). Book Kvalitet och innehåll i patientregistret. Utskrivningar från slutenvården 19642007 och besök i specialiserad öppenvård (exklusive primärvårdsbesök) 19972007. (Quality and content of the Patient Register)(2009-125-15). (Editor ed. ^eds.). City 2009.

3. Ludvigsson JF, Otterblad-Olausson P, Pettersson BU, Ekbom A: The Swedish personal identity number: possibilities and pitfalls in healthcare and medical research. Eur J Epidemiol 2009, 24:659-667.

4. Mattsson B, Wallgren A: Completeness of the Swedish Cancer Register. Non-notified cancer cases recorded on death certificates in 1978. Acta Radiol Oncol 1984, 23:305-313.

5. Johansson LA, Westerling R: Comparing Swedish hospital discharge records with death certificates: implications for mortality statistics. Int $J$ Epidemiol 2000, 29:495-502.

6. SNBHW: The Swedish Medical Birth Register: a summary of content and quality. Book The Swedish Medical Birth Register: a summary of content and quality. (Editor ed.^eds.) City: Swedish National Board of Health and Welfare; 2003 [http://www.sos.se/fulltext/112/2003-112-3/2003-112-3.pdf].

7. Nilsson AC, Spetz CL, Carsjo K, Nightingale R, Smedby B: Reliability of the hospital registry. The diagnostic data are better than their reputation. Lakartidningen 1994, 91:598, 603-595.

8. Carjsö K, Smedby B, Spetz CL: Evaluation of the Data quality in the Swedish National Hospital Discharge Register. Book Evaluation of the Data quality in the Swedish National Hospital Discharge Register (Editor ed.^eds.). pp. 1-10. City: WHO/HST/ICD/C/98.34 1998, 1-10.

9. Kouchecki B, Köster M, Eckerström L, Wiberg-Hedman K: Bilaga 1-3 till Öppna jämförelser av hälso- och sjukvårdens kvalitet och effektivitet 2009. Book Bilaga 1-3 till Öppna jämförelser av hälso- och sjukvårdens kvalitet och effektivitet 2009. (Editor ed.^eds.) City: Socialstyrelsen (National Board of Health and Welfare); 2009.
10. Fang F, Valdimarsdottir U, Bellocco R, Ronnevi LO, Sparen P, Fall K, Ye W: Amyotrophic lateral sclerosis in Sweden, 1991-2005. Arch Neurol 2009, 66:515-519

11. Jonas E, Marsk R, Rasmussen F, Freedman J: Incidence of postoperative gallstone disease after antiobesity surgery: population-based study from Sweden. Surg Obes Relat Dis 2010, 6:54-58.

12. Knight A, Askling J, Ekbom A: Cancer incidence in a population-based cohort of patients with Wegener's granulomatosis. Int J Cancer 2002, 100:82-85.

13. Sorensen $H T$, Sabroe $\mathrm{S}$, Olsen J: A framework for evaluation of secondary data sources for epidemiological research. Int J Epidemiol 1996, 25:435-442.

14. Elo SL, Karlberg $\mathbb{H}$ : Validity and utilization of epidemiological data: a study of ischaemic heart disease and coronary risk factors in a local population. Public Health 2009, 123:52-57.

15. Troeng T, Malmstedt J, Bjorck M: External validation of the Swedvasc registry: a first-time individual cross-matching with the unique personal identity number. Eur J Vasc Endovasc Surg 2008, 36:705-712.

16. Backe SN, Andersson R: Monitoring the "tip of the iceberg": ambulance records as a source of injury surveillance. Scand J Public Health 2008, 36:250-257.

17. Nordgren C: On the need of validating inpatient registers. Spinal Cord 2008, 46:748-752.

18. Vestergaard M, Obel C, Henriksen TB, Christensen J, Madsen KM, Ostergaard JR, Olsen J: The Danish National Hospital Register is a valuable study base for epidemiologic research in febrile seizures. J Clin Epidemiol 2006, 59:61-66.

19. Madsen M, Davidsen M, Rasmussen S, Abildstrom SZ, Osler M: The validity of the diagnosis of acute myocardial infarction in routine statistics: a comparison of mortality and hospital discharge data with the Danish MONICA registry. J Clin Epidemiol 2003, 56:124-130.

20. Severinsen MT, Kristensen SR, Overvad K, Dethlefsen C, Tjonneland A, Johnsen SP: Venous thromboembolism discharge diagnoses in the Danish National Patient Registry should be used with caution. J Clin Epidemiol 63:223-228.

21. Ron E, Gridley G, Hrubec Z, Page W, Arora S, Fraumeni JF Jr: Acromegaly and gastrointestinal cancer. Cancer 1991, 68:1673-1677.

22. Baecklund E, lliadou A, Askling J, Ekbom A, Backlin C, Granath F, Catrina Al, Rosenquist R, Feltelius N, Sundstrom C, Klareskog L: Association of chronic inflammation, not its treatment, with increased lymphoma risk in rheumatoid arthritis. Arthritis Rheum 2006, 54:692-701.

23. Ludvigsson JF, Olen O, Bell M, Ekbom A, Montgomery SM: Coeliac disease and risk of sepsis. Gut 2008, 57:1074-1080.

24. Parikh NI, Cnattingius S, Dickman PW, Mittleman MA, Ludvigsson JF, Ingelsson E: Parity and risk of later-life maternal cardiovascular disease. Am Heart J 159:215-221, e216.

25. Fazel S, Langstrom N, Hjern A, Grann M, Lichtenstein P: Schizophrenia, substance abuse, and violent crime. JAMA 2009, 301:2016-2023.

26. Blomqvist $\mathrm{P}$ : On the use of administrative databases in health care analyses (Dissertation). Karolinska Institutet 1998.

27. Heurgren M, Serden L: Patientregistret för 2008 ur ett DRG-perspektiv. (The Patient Register from a DRG perspective)(2010-4-14). Book Patientregistret för 2008 ur ett DRG-perspektiv. (The Patient Register from a DRG perspective)(2010-4-14). (Editor ed.^eds.). City 2009.

28. Collaborative systematic review of the randomised trials of organised inpatient (stroke unit) care after stroke. Stroke Unit Trialists' Collaboration. BMJ 1997, 314:1151-1159.

29. Ludvigsson JF, Montgomery SM, Ekbom A, Brandt L, Granath F: Smallintestinal histopathology and mortality risk in celiac disease. JAMA 2009, 302:1171-1178.

30. Elmberg M, Hultcrantz R, Ebrahim F, Olsson $S$, Lindgren $S$, Loof L, Stal P, Wallerstedt S, Almer S, Sandberg-Gertzen H, et al: Increased mortality risk in patients with phenotypic hereditary hemochromatosis but not in their first-degree relatives. Gastroenterology 2009, 137:1301-1309.

31. Berkson J: Limitations of the application of fourfold tables to hospital data. Biometrics Bulletin 1946, 2:47-53.

32. Gedeborg R, Engquist $H$, Berglund L, Michaelsson K: Identification of incident injuries in hospital discharge registers. Epidemiology 2008, 19:860-867. 
33. Kljakovic M, Abernethy D, de Ruiter I: Quality of diagnostic coding and information flow from hospital to general practice. Inform Prim Care 2004, 12:227-234.

34. Linnersjo A, Hammar N, Gustavsson A, Reuterwall C: Recent time trends in acute myocardial infarction in Stockholm, Sweden. Int J Cardiol 2000, 76:17-21.

35. Guidelines for the diagnosis of heart failure. The Task Force on Heart Failure of the European Society of Cardiology. Eur Heart J 1995, 16:741-751.

36. Ingelsson E, Arnlov J, Sundstrom J, Lind L: The validity of a diagnosis of heart failure in a hospital discharge register. Eur J Heart Fail 2005, 7:787-791.

37. Smith JG, Platonov PG, Hedblad B, Engstrom G, Melander O: Atrial fibrillation in the Malmo diet and cancer study: a study of occurrence, risk factors and diagnostic validity. Eur J Epidemiol 2009, 25:95-102.

38. Stegmayr B, Asplund K: Measuring stroke in the population: quality of routine statistics in comparison with a population-based stroke registry. Neuroepidemiology 1992, 11:204-213.

39. Ros HS, Cnattingius S, Lipworth L: Comparison of risk factors for preeclampsia and gestational hypertension in a population-based cohort study. Am J Epidemiol 1998, 147:1062-1070.

40. Hultgren R, Olofsson P, Wahlberg E: Gender differences in vascular interventions for lower limb ischaemia. Eur J Vasc Endovasc Surg 2001, 21:22-27.

41. Arnett FC, Edworthy SM, Bloch DA, McShane DJ, Fries JF, Cooper NS, Healey LA, Kaplan SR, Liang MH, Luthra HS, et al: The American Rheumatism Association 1987 revised criteria for the classification of rheumatoid arthritis. Arthritis Rheum 1988, 31:315-324.

42. Turesson C, Jacobsson L, Bergstrom U: Extra-articular rheumatoid arthritis: prevalence and mortality. Rheumatology (Oxford) 1999, 38:668-674.

43. Leavitt RY, Fauci AS, Bloch DA, Michel BA, Hunder GG, Arend WP Calabrese LH, Fries JF, Lie JT, Lightfoot RW Jr, et al: The American College of Rheumatology 1990 criteria for the classification of Wegener's granulomatosis. Arthritis Rheum 1990, 33:1101-1107.

44. Smedby KE, Akerman M, Hildebrand H, Glimelius B, Ekbom A, Askling J: Malignant lymphomas in coeliac disease: evidence of increased risks for lymphoma types other than enteropathy-type T cell lymphoma. Gut 2005, 54:54-59.

45. Bensing S, Brandt L, Tabaroj F, Sjoberg O, Nilsson B, Ekbom A, Blomqvist P, Kampe $O$ : Increased death risk and altered cancer incidence pattern in patients with isolated or combined autoimmune primary adrenocortical insufficiency. Clin Endocrinol (Oxf) 2008, 69:697-704.

46. Ragnarson Tennvall G, Apelqvist J, Eneroth M: The inpatient care of patients with diabetes mellitus and foot ulcers. A validation study of the correspondence between medical records and the Swedish Inpatient Registry with the consequences for cost estimations. J Intern Med 2000, 248:397-405

47. Ekbom A, Helmick C, Zack M, Adami HO: The epidemiology of inflammatory bowel disease: a large, population-based study in Sweden. Gastroenterology 1991, 100:350-358.

48. Ekholm B, Ekholm A, Adolfsson R, Vares M, Osby U, Sedvall GC, Jonsson EG: Evaluation of diagnostic procedures in Swedish patients with schizophrenia and related psychoses. Nord J Psychiatry 2005, 59:457-464.

49. Dalman C, Broms J, Cullberg J, Allebeck P: Young cases of schizophrenia identified in a national inpatient register-are the diagnoses valid? SoC Psychiatry Psychiatr Epidemiol 2002, 37:527-531.

50. Lichtenstein P, Bjork C, Hultman CM, Scolnick E, Sklar P, Sullivan PF: Recurrence risks for schizophrenia in a Swedish national cohort. Psychol Med 2006, 36:1417-1425.

51. Reutfors J: Life time OPCRIT generated DSM-IV diagnoses among patients with an initial clinical ICD schizophrenia spectrum diagnosis. 29th Nordic Congress of Psychiatr; Stockholm 2009.

52. Kristjansson E, Allebeck P, Wistedt B: Validity of the diagnosis schizophrenia in a psychiatric inpatient register. 1987, 41:229-234.

53. Bergman B, Belfrage H, Grann M: Mentally disorderd offenders in Sweden: Forensic and general psychiatric diagnoses. American Journal of Forensic Psychiatry 1999, 20:27-37.

54. Jin YP, Gatz M, Johansson B, Pedersen NL: Sensitivity and specificity of dementia coding in two Swedish disease registries. Neurology 2004, 63:739-741.
55. Grann M, Haggård U, Tengström A, Woodhouse A, Långström N, Holmberg G, Kullgren G: Some experiences from registers of interest to forensic research in Sweden. Scand J Forensic Science 1998, 78-80.

56. Criteria for diagnosis of Guillain-Barre syndrome. Ann Neurol 1978, 3:565-566.

57. Jiang GX, de Pedro-Cuesta J, Fredrikson S: Guillain-Barre syndrome in south-west Stockholm, 1973-1991, 1. Quality of registered hospital diagnoses and incidence. Acta Neurol Scand 1995, 91:109-117.

58. Hjalmarsson A, Blomqvist $P$, Skoldenberg B: Herpes simplex encephalitis in Sweden, 1990-2001: incidence, morbidity, and mortality. Clin Infect Dis 2007, 45:875-880

59. Michaelsson K, Baron JA, Farahmand BY, Johnell O, Magnusson C, Persson PG, Persson I, Ljunghall S: Hormone replacement therapy and risk of hip fracture: population based case-control study. The Swedish Hip Fracture Study Group. Bmj 1998, 316:1858-1863.

60. Andersson R, Hugander A, Thulin A, Nystrom PO, Olaison G: Indications for operation in suspected appendicitis and incidence of perforation. Bmj 1994, 308:107-110

61. Zendehdel K, Nyren O, Edberg A, Ye W: Risk of Esophageal Adenocarcinoma in Achalasia Patients, a Retrospective Cohort Study in Sweden. Am J Gastroenterol 2007.

62. Nyren O, Yin L, Josefsson S, McLaughlin JK, Blot WJ, Engqvist M, Hakelius L, Boice JD, Adami HO: Risk of connective tissue disease and related disorders among women with breast implants: a nation-wide retrospective cohort study in Sweden. Bmj 1998, 316:417-422.

63. Merlo J, Lindblad U, Pessah-Rasmussen H, Hedblad B, Rastam J, Isacsson SO, Janzon L, Rastam L: Comparison of different procedures to identify probable cases of myocardial infarction and stroke in two Swedish prospective cohort studies using local and national routine registers. Eur J Epidemiol 2000, 16:235-243.

64. Ahlbom A: Acute myocardial infarction in Stockholm-a medical information system as an epidemiological tool. Int J Epidemiol 1978, 7:271-276.

65. Hammar N, Nerbrand C, Ahlmark G, Tibblin G, Tsipogianni A, Johansson S, Wilhelmsen L, Jacobsson S, Hansen $\mathrm{O}$ : Identification of cases of myocardial infarction: hospital discharge data and mortality data compared to myocardial infarction community registers. Int J Epidemiol 1991, 20:114-120.

66. Forberg JL, Green M, Bjork J, Ohlsson M, Edenbrandt L, Ohlin H, Ekelund U: In search of the best method to predict acute coronary syndrome using only the electrocardiogram from the emergency department. J Electrocardiol 2009, 42:58-63.

67. Hallstrom B, Jonsson AC, Nerbrand C, Petersen B, Norrving B, Lindgren A: Lund Stroke Register: hospitalization pattern and yield of different screening methods for first-ever stroke. Acta Neurol Scand 2007, 115:49-54.

68. Wirehn AB, Karlsson HM, Carstensen JM: Estimating disease prevalence using a population-based administrative healthcare database. Scand J Public Health 2007, 35:424-431.

69. Gedeborg R, Furebring M, Michaelsson K: Diagnosis-dependent misclassification of infections using administrative data variably affected incidence and mortality estimates in ICU patients. J Clin Epidemiol 2007, 60:155-162.

70. Askling J, Fored CM, Brandt L, Baecklund E, Bertilsson L, Coster L, Geborek P, Jacobsson LT, Lindblad S, Lysholm J, et al: Risk and case characteristics of tuberculosis in rheumatoid arthritis associated with tumor necrosis factor antagonists in Sweden. Arthritis Rheum 2005, 52:1986-1992

71. Dahl A, Berg S, Nilsson SE: Identification of dementia in epidemiological research: a study on the usefulness of various data sources. Aging Clin Exp Res 2007, 19:381-389.

72. Fratiglioni L, Viitanen M, Backman L, Sandman PO, Winblad B: Occurrence of dementia in advanced age: the study design of the Kungsholmen Project. Neuroepidemiology 1992, 11(Suppl 1):29-36.

\section{Pre-publication history}

The pre-publication history for this paper can be accessed here: http://www.biomedcentral.com/1471-2458/11/450/prepub

\section{doi:10.1186/1471-2458-11-450}

Cite this article as: Ludvigsson et al:: External review and validation of the Swedish national inpatient register. BMC Public Health 2011 11:450. 